\title{
The Southern Ocean as a constraint to reduce uncertainty in future ocean carbon sinks
}

\author{
A. Kessler ${ }^{1,2}$ and J. Tjiputra ${ }^{1}$ \\ ${ }^{1}$ Uni Research Climate, Bjerknes Centre for Climate Research, Bergen, Norway \\ ${ }^{2}$ Pierre and Marie Curie University, Paris, France \\ Correspondence to: J. Tjiputra (jerry.tjiputra@uni.no)
}

Received: 25 November 2015 - Published in Earth Syst. Dynam. Discuss.: 21 December 2015

Revised: 4 March 2016 - Accepted: 15 March 2016 - Published: 7 April 2016

\begin{abstract}
Earth system model (ESM) simulations exhibit large biases compares to observation-based estimates of the present ocean $\mathrm{CO}_{2}$ sink. The inter-model spread in projections increases nearly 2 -fold by the end of the 21 st century and therefore contributes significantly to the uncertainty of future climate projections. In this study, the Southern Ocean (SO) is shown to be one of the hot-spot regions for future uptake of anthropogenic $\mathrm{CO}_{2}$, characterized by both the solubility pump and biologically mediated carbon drawdown in the spring and summer. We show, by analyzing a suite of fully interactive ESMs simulations from the Coupled Model Intercomparison Project phase 5 (CMIP5) over the 21st century under the high- $\mathrm{CO}_{2}$ Representative Concentration Pathway (RCP) 8.5 scenario, that the $\mathrm{SO}$ is the only region where the atmospheric $\mathrm{CO}_{2}$ uptake rate continues to increase toward the end of the 21st century. Furthermore, our study discovers a strong inter-model link between the contemporary $\mathrm{CO}_{2}$ uptake in the Southern Ocean and the projected global cumulated uptake over the 21st century. This strong correlation suggests that models with low (high) carbon uptake rate in the contemporary SO tend to simulate low (high) uptake rate in the future. Nevertheless, our analysis also shows that none of the models fully capture the observed biophysical mechanisms governing the $\mathrm{CO}_{2}$ fluxes in the SO. The inter-model spread for the contemporary $\mathrm{CO}_{2}$ uptake in the Southern Ocean is attributed to the variations in the simulated seasonal cycle of surface $p \mathrm{CO}_{2}$. Two groups of model behavior have been identified. The first one simulates anomalously strong SO carbon uptake, generally due to both too strong a net primary production and too low a surface $p \mathrm{CO}_{2}$ in December-January. The second group simulates an opposite $\mathrm{CO}_{2}$ flux seasonal phase, which is driven mainly by the bias in the sea surface temperature variability. We show that these biases are persistent throughout the $21 \mathrm{st}$ century, which highlights the urgent need for a sustained and comprehensive biogeochemical monitoring system in the Southern Ocean to better constrain key processes represented in current model systems.
\end{abstract}

\section{Introduction}

Since the industrial revolution, a steady increase in anthropogenic $\mathrm{CO}_{2}$ emissions from fossil fuel burning, cement production, and land-use change have led to an increase in atmospheric $\mathrm{CO}_{2}$ concentration of about $43 \%$ in 2014 relative to its preindustrial value according to the latest measurements from the Earth System Research Laboratory in Mauna Loa (www.esrl.noaa.gov). This represents the highest $\mathrm{CO}_{2}$ concentration for at least the last 800000 years. Increasing atmospheric $\mathrm{CO}_{2}$ is one of the most important drivers for ongoing, and likely future, climate change, and it affects the ocean carbon reservoir. By taking up about approximately $26 \%$ of the anthropogenic $\mathrm{CO}_{2}$ emissions annually (Le Quéré et al., 2015), the ocean slows down the growth of the atmospheric $\mathrm{CO}_{2}$ concentration and therefore the rate of climate change. However, the ocean carbon uptake rate will decrease in the future owing to the lowered buffer capacity of the surface waters and the potential weakening of carbon transport from the surface to the deep ocean, leading to a positive climate feedback (Arora et al., 2013; Heinze et al., 2015).

The oceanic carbon sink is mainly controlled by the physical and the biological pumps, which are both affected by 
the changing climate (Volk and Hoffert, 1985). The physical pump depends mainly on two processes: dissolution of $\mathrm{CO}_{2}$ gas in seawater and transportation of dissolved inorganic carbon into the deep ocean by mixing and circulation processes. The biological pump is predominantly governed by the population of marine phytoplankton, which consumes the dissolved inorganic carbon (DIC) in the seawater to produce organic matter or soft tissue via photosynthesis. Through gravitational forcing, this organic matter sinks into the ocean interior where it is remineralized back into DIC. The biological pump is also affected by the global increase in temperature and by changes in circulation. The solubility of atmospheric $\mathrm{CO}_{2}$ in the ocean's surface is expected to be negatively impacted by global warming since the solubility of $\mathrm{CO}_{2}$ gas in seawater decreases with warmer temperatures (Sarmiento et al., 1998). Additionally, the oceanic circulation that links the low DIC in the ocean surface to the $\mathrm{CO}_{2}$-rich deep ocean could be altered in the next few decades through weaker upwelling and a slowdown in the Atlantic meridional overturning circulation (AMOC) (Rahmstorf et al., 2015). Both of these carbon pump processes are represented in the latest earth system model (ESM) simulations from CMIP5, which include for the first time a coupling between the atmosphere-ocean global climate models (AOGCMs, as in previous CMIPs) and the biogeochemical fluxes between the ocean, atmosphere, and terrestrial biosphere reservoirs (Taylor et al., 2012).

It has been shown that the trend in current anthropogenic $\mathrm{CO}_{2}$ emissions closely follows the Representative Concentration Pathway (RCP) 8.5 scenario (Peters et al., 2013; Fuss et al., 2014), which is the most pessimistic future scenario, with high atmospheric $\mathrm{CO}_{2}$ concentrations leading to $8.5 \mathrm{Wm}^{-2}$ additional radiative forcing by 2100 . The estimated emissions reached $37.0 \pm 1.3 \mathrm{Gt} \mathrm{CO}_{2} \mathrm{yr}^{-1}$ in 2014 (Friedlingstein et al., 2014), matching the RCP8.5 scenario leading to the highest increase in global mean temperature from 3.2 to $5.4^{\circ} \mathrm{C}$ at the end of this century relative to 1850 1900. This study focuses on analyzing the fully interactive ESM simulations from CMIP5 for the 2001 to 2099 period from the experiments "esmHistorical" and "esmrcp8.5". We compare the 2001-2010 period from the simulations with observational data.

Figure 1 presents the time series of the global annual $\mathrm{CO}_{2}$ uptake by the ocean computed from nine different CMIP5 models (Sect. 2.2) from the years 2001 to 2099, including the observation-based estimate of carbon flux for the period 1998-2011 (Landschützer et al., 2014). In addition to the large present-day inter-model spread, the figure also highlights the increase in the inter-model spread projected into the future. The magnitude of the standard deviation (i.e., of the inter-model variation) increases by a factor of 2 from $2001\left( \pm 0.3 \mathrm{PgC} \mathrm{yr}^{-1}\right)$ to $2099\left( \pm 0.6 \mathrm{PgC} \mathrm{yr}^{-1}\right)$. During this period, the projected cumulative oceanic carbon sink ranges from 340.4 to $488.5 \mathrm{Pg} \mathrm{C}$. The $148 \mathrm{Pg} \mathrm{C}$ difference in the size of the ocean carbon sink translates into roughly a $70 \mathrm{ppm}$ dif-

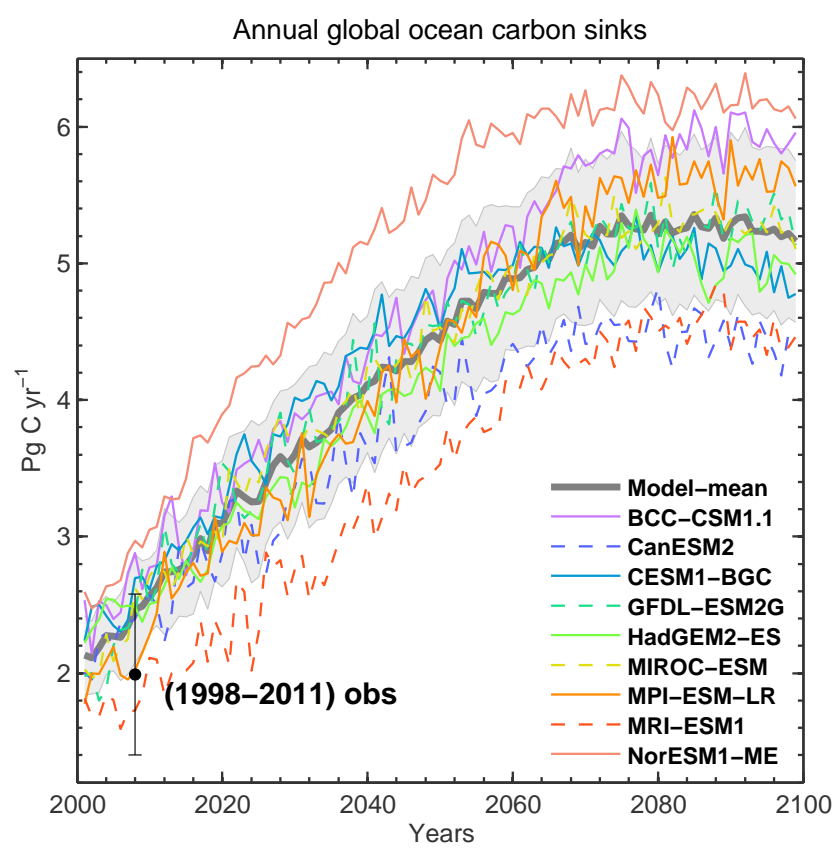

Figure 1. Time series of annual ocean carbon uptake as simulated by nine ESMs for the 2001-2100 period. Thick gray line indicates the multi-model mean, shaded areas represent \pm one standard deviation of the inter-model variations. The observation-based estimate (black circle) is from Landschützer et al. (2014).

ference in atmospheric $\mathrm{CO}_{2}$ concentration by the end of the 21 st century. In order to improve the fidelity of future projections provided by the climate modeling community, it is necessary to identify and attribute the mechanisms responsible for the growth in the inter-model spread of ocean $\mathrm{CO}_{2}$ uptake and to determine methods to constrain this. Motivated by these growing uncertainties and the need to constrain them, our study focuses on analyzing relationships between regional and global uncertainties in ocean carbon uptakes as simulated in CMIP5 models. This is necessary because the strength and variability of the ocean carbon sinks vary considerably from one region to another and are attributed to region-specific mechanisms. For instance, in the equatorial Pacific, the long-term trend in $\mathrm{CO}_{2}$ uptake is strongly influenced by the El Niño variability (Feely et al., 2006). In other regions, such as the Southern Ocean, the variability is related to the Southern Annular Mode (see, e.g., Le Quéré et al., 2007; Landschützer et al., 2015).

The need to reduce this inter-model spread is imperative to reduce uncertainty in future climate projections and enable policy makers to make the most informed decisions. The simulated uncertainty in ocean carbon uptake could arise from different factors. Feedbacks from ocean and terrestrial biospheres on the $\mathrm{CO}_{2}$ concentration are expected but highly uncertain and thus difficult to predict (Denman et al., 2007). Differences in (i) basin-scale ocean evolution of ocean carbon uptake rates, (ii) timing and amplitude of physical and 
biogeochemical processes driving the regional $\mathrm{pCO}_{2}$ seasonal cycle, as well as (iii) responses to transient future climate change are among potential contributors to future uncertainty in ocean carbon uptake, and addressing these points will be the main focus of this study.

The paper is organized as follows: in the next section we describe the observations and models used in this study as well as the terms and metrics used to investigate the relationships between present-day and future carbon uptake and the regional boundaries. Section 3 discusses the results of the analyses. Additional discussions and comparison with previous studies are presented in Sect. 4. Finally, the study is summarized in Sect. 5.

\section{Methods}

\subsection{Observation-based estimates}

We used the monthly data set documented by Landschützer et al. (2014) for the 2001-2010 period. It includes the surface ocean partial pressure of $\mathrm{CO}_{2}\left(p \mathrm{CO}_{2}\right)$ and the sea-air $\mathrm{CO}_{2}$ flux $\left(\mathrm{fgCO}_{2}\right)$ gridded with a $1^{\circ} \times 1^{\circ}$ horizontal resolution corresponding to 360 by 180 points in longitude and latitude, respectively. The $p \mathrm{CO}_{2}$ data set is originally extrapolated in space and time from SOCAT (Surface Ocean $\mathrm{CO}_{2}$ Atlas) version 2 (Bakker et al., 2014) by a two-step neuralnetwork approach as described in Landschützer et al. (2013). The sea-air $\mathrm{CO}_{2}$ flux is computed based on this $p \mathrm{CO}_{2}$ field, applying a standard bulk formulation and high-resolution Cross-Calibrated Multi-Platform (CCMP) wind speeds (Atlas et al., 2011). The monthly averaged sea surface salinity (SSS) was downloaded from the Simple Ocean Data Assimilation (SODA; Carton and Giese, 2008) and has been regridded to the $p \mathrm{CO}_{2}$ data set. The sea surface temperature (SST) is from the National Oceanic and Atmospheric Administration (NOAA) Optimum Interpolation (OI) sea surface v.2 (Reynolds et al., 2002).

The climatology of net primary production (NPP) used for the seasonal model-data assessment in the Southern Ocean (Sect. 3.2) is documented by Nevison et al. (2015) and is computed over the 1997-2010 period using data derived from the Sea-viewing Wide Field-of-view Sensor (SeaWiFS). It uses an empirical chlorophyll (Chl) algorithm for the Southern Hemisphere that was tuned to in situ $\mathrm{Chl}$ in the Southern Ocean and spatially blended with the standard SeaWiFS Ocean Color (OC) 4 algorithm (Kahru and Mitchell, 2010).

\section{$2.2 \mathrm{pCO}_{2}$ decomposition}

In order to allow decomposition of $p \mathrm{CO}_{2}$ variability into its physical and biogeochemical components, we estimated the alkalinity (ALK) and DIC at the same resolution as the $p \mathrm{CO}_{2}$ data. The alkalinity was computed from the SST and SSS estimates depending on the region using the Lee et al.
(2006) formulation. When temperatures are out of range in the selected region, the computation returns a missing value $(\mathrm{NaN})$. The DIC was computed using the $\mathrm{CO}_{2}$ inorganic carbon chemistry program CO2SYS developed in Matlab (van Heuven et al., 2011) using the gridded SST, SSS, $p \mathrm{CO}_{2}$, and alkalinity as input parameters. The global average surface silicate and the phosphate concentrations were used: 10 and $0.75 \mu \mathrm{mol} \mathrm{kg} \mathrm{S} \mathrm{W}^{-1}$, respectively. We expect that this choice has a relatively small influence on our results since a shift in the concentration of silicate and phosphate by 4 and more than 6 times to their original mean values would generate only a 0.05 and $0.2 \%$ change in the DIC computation. To complete the CO2SYS input, we applied the dissociation constants K1 and K2 introduced by Mehrbach et al. (1973) and refitted by Dickson and Millero (1987).

Decomposition of the total $p \mathrm{CO}_{2}$ seasonal variability was based on the following approximation (Tjiputra et al., 2014):

$\frac{\mathrm{d} p \mathrm{CO}_{2}^{\text {tot }}}{\mathrm{d} t} \approx \frac{\mathrm{d} p \mathrm{CO}_{2}^{\text {DIC }}}{\mathrm{d} t}+\frac{\mathrm{d} p \mathrm{CO}_{2}^{\mathrm{ALK}}}{\mathrm{d} t}+\frac{\mathrm{d} p \mathrm{CO}_{2}^{\text {SST }}}{\mathrm{d} t}+\frac{\mathrm{d} p \mathrm{CO}_{2}^{\text {SSS }}}{\mathrm{d} t}$,

where the $p \mathrm{CO}_{2}^{\text {tot }}$ variation in time $\left(\mathrm{d} p \mathrm{CO}_{2}^{\text {tot }} / d \mathrm{t}\right)$ is approximately equal to the sum of the four decomposed $p \mathrm{CO}_{2}^{x}$ variations in time, where $x$ is DIC, ALK, SST, or SSS. The $p \mathrm{CO}_{2}^{x}$ terms represent a set of thermodynamic equations that relates to the inorganic carbon species, taking into account variation in $x$, while the other components are kept at their long-term local average values. In this way, $\mathrm{d} p \mathrm{CO}_{2}^{\mathrm{DIC}} / \mathrm{d} t$ is an estimate of the temporal variability of the local $p \mathrm{CO}_{2}$ field as a result of changing DIC only. The same estimates were applied for the other three parameters (i.e., ALK, SST, and SSS).

\subsection{Model descriptions and post processing}

The nine participating CMIP5 ESMs in alphabetical order, are the (1) Beijing Climate Center Climate System Model (BCC-CSM1.1(m)), (2) Canadian Centre for Climate Modelling and Analysis ESM (CanESM2), (3) Community Earth System Model (CESM1-BGC), (4) Geophysical Fluid Dynamics Laboratory ESM (GFDL-ESM2G), (5) Hadley Global Environment Model 2 (HadGEM2-ES), (6) Japan Agency for Marine-Earth Science and Technology (MIROCESM), (7) Max Planck Institute for Meteorology ESM (MPI-ESM-LR), (8) Japanese Meteorology Research Institute ESM (MRI-ESM1), and (9) Norwegian Climate Centre ESM (NorESM1-ME). These models have also contributed to the last Intergovernmental Panel on Climate Change Assessment Report (IPCC-AR5). All outputs were downloaded directly from the Earth System Grid Federation (ESGF; http: //esgf.llnl.gov), and we analyzed the fully interactive $\mathrm{CO}_{2}$ emissions-based "esm" simulations. These esm simulations take into account carbon fluxes between the land-atmosphere and ocean-atmosphere interfaces to prognostically simulate the atmospheric $\mathrm{CO}_{2}$ concentration; thus, they include more realistic spatially varying atmospheric $\mathrm{CO}_{2}$ concentration. The selection of these models is based on the availability of 
all variables necessary to discuss the impact of the $p \mathrm{CO}_{2}$ seasonal cycle on the carbon uptake: $\mathrm{fgCO}_{2}, p \mathrm{CO}_{2}$, SST, SSS, DIC, ALK, and NPP. However, the BCC-CSM1.1 and the MIROC-ESM models do not provide some of these variables (ALK and DIC) and therefore were only analyzed for the contemporary and future uptake relationship (Sect. 3.1). In order to compare the global and regional $\mathrm{fgCO}_{2}$ between the models presented in Sect. 3.1, $\mathrm{fgCO}_{2}$ outputs were also interpolated to the observational grid of $360 \times 180$ points. Model outputs from the historical (esmHistorical) experiments were added to the RCP8.5 (esmrcp8.5) to complete the 2001-2099 period of study. We used the same "rlilp1" realization from each model. Tables 1 and 2 summarize the physical and marine biogeochemical components and features of each model.

The marine primary productivity is one of the key components that governs the carbon cycle in the ocean, impacting the oceanic pump through alteration of the buffering capacity and the $\mathrm{CO}_{2}$ remaining in the atmosphere. The ocean NPP is controlled by nutrient availability and other physical factors such as temperature and light. As presented in Table 2, the CMIP5 models use different representations of multiple nutrient limitations, varying from one to five explicit nutrients in CMOC-NPZD and BEC-TOPAZ2 and from one to three phytoplankton species, NPZD-HAMOCC-CMOC and BECTOPAZ2. This highlights the wide range of biogeochemistry complexity, which can also contribute to the inter-model spread in their respective outputs. We note that the MOM4L40 uses the OCMIP2 biogeochemistry module, which does not include an explicit marine ecosystem; therefore, in this case the primary production is simulated only as a function of surface phosphate concentration.

\subsection{Uptake efficiency}

In Sect. 3.2 we compute for each model (at the original model resolution) the "uptake efficiency" (uptake ${ }_{\text {eff }}^{y}$ ) of carbon in the ocean, where $y$ represents the different basin regions as defined in Sect. 2.6 as well as the global (glb) and other ocean region excluding the $\mathrm{SO}(\mathrm{eSO})$. The uptake eff $_{\text {measures the }}$ efficiency of a specific water mass in taking up carbon for a given change in atmospheric $p \mathrm{CO}_{2}$. A high uptake eff value represents a good capacity of the ocean to contain DIC for a certain change in atmospheric $p \mathrm{CO}_{2}$ and vice versa. This term is computed as follows:

uptake $_{\mathrm{eff}}^{y}=\frac{\partial\left[\mathrm{CT}^{y}\right]}{\partial\left[p \mathrm{CO}_{2}^{y}\right]}=\frac{\mathrm{DIC}^{y}}{p \mathrm{CO}_{2}^{y} \mathrm{RF}^{y}}$.

The $\mathrm{DIC}^{y}$ and $p \mathrm{CO}_{2}^{y}$ in Eq. (2) represent the respective area-weighted mean surface concentration of DIC and $p \mathrm{CO}_{2}^{y}$ within the domain $y . \mathrm{RF}^{y}$ is the regional mean Revelle Factor (RF) (Revelle and Suess, 1957), also known as the inverse of the ocean's buffering capacity for atmospheric $\mathrm{CO}_{2}$ uptake, i.e., to convert $\mathrm{CO}_{2 \text {,aq }}$ into different carbon species (carbonate and bicarbonate) within domain $y$. Water masses with a lower Revelle Factor are more efficient at taking up anthropogenic carbon (Sabine et al., 2004). The increase in atmospheric $\mathrm{CO}_{2}$ has pushed the surface $\mathrm{CO}_{2 \text {,aq }}$ concentration to a higher level, resulting in an increase in the Revelle Factor (Zeebe and Wolf-Gladrow, 2001) and thus a decrease in ocean's buffering capacity. This mechanism represents a positive climate feedback, which reduces the uptake rate of atmospheric $\mathrm{CO}_{2}$ in the future (Wallace, 2001). The DIC and $p \mathrm{CO}_{2}$ fields were taken directly from the model outputs, whereas the RF were computed with CO2SYS.

\subsection{Inter-model correlation}

In order to assess qualitatively the existence of any patterns or consistencies between the simulated $\mathrm{CO}_{2}$ uptakes among the different models, two metrics of inter-model correlation coefficients have been computed: $R_{\text {mean }}^{y}$ and $R_{\text {cum. }}^{y}$. A high correlation coefficient indicates a strong relationship between the contemporary and the projected inter-model spread. Moreover, a statistically significant positive correlation coefficient denotes that models that project weak (high) uptake in the contemporary period tend to project weak (high) future uptake. The two correlation coefficients were computed as follows:

$$
\begin{aligned}
R_{\text {mean }}^{y} & =\text { CorrCoef }\left[\frac{1}{10} \sum_{t=2001}^{2010} \mathrm{fgCO}_{2}^{y}(t), \frac{1}{10} \sum_{t=2090}^{2099} \mathrm{fgCO}_{2}^{\mathrm{glb}}(t)\right] \\
, R_{\text {cum }}^{y} & =\text { CorrCoeff }\left[\frac{1}{10} \sum_{t=2001}^{2010} \mathrm{fgCO}_{2}^{y}(t), \sum_{t=2001}^{2099} \mathrm{fgCO}_{2}^{\mathrm{glb}}(t)\right]
\end{aligned}
$$

$R_{\text {mean }}^{y}$ represents the inter-model correlation coefficient between contemporary annual mean $\mathrm{CO}_{2}$ uptake in the different $y$ regions and global uptake rate in the last decade of the 21st century (i.e., 2090-2099). Then, $R_{\text {cum }}^{y}$ represents the inter-model correlation coefficient between the contemporary annual mean uptake rate and the cumulative global carbon uptake over the 2001-2099 period.

\subsection{Regional boundaries}

Regional characteristics of anthropogenic-carbon uptake can be assessed through division of the global ocean into eight basin-scale regions. The regional distribution is defined according to the low, mid- and high latitudes, motivated by the large-scale difference in carbon uptake mechanisms occurring in these regions (see, e.g., Mikaloff Fletcher et al., 2007). The regions are as follows: Southern Ocean (SO; $\left.45-70^{\circ} \mathrm{S}\right)$, midlatitude Southern Ocean $\left(\mathrm{mSO} ; 15-45^{\circ} \mathrm{S}\right)$, tropical Pacific (TPa; $15^{\circ} \mathrm{N}-15^{\circ} \mathrm{S}$ ), tropical Atlantic (TAt; $15^{\circ} \mathrm{N}-15^{\circ} \mathrm{S}$ ), Indian Ocean (Ind; north of $15^{\circ} \mathrm{S}$ ), North Pacific $\left(\mathrm{NPa} ; 15-60^{\circ} \mathrm{N}\right)$, North Atlantic (NAt; $\left.15-60^{\circ} \mathrm{N}\right)$, and Arctic Ocean (Arc; $\left.>60^{\circ} \mathrm{N}\right)$. Computation for the analysis pertaining to the relationships between contemporary and future $\mathrm{CO}_{2}$ uptake (Sect. 3.1) is made at the resolution of the observational data. 
Table 1. Description of the models analyzed in this study, indicating ocean model resolutions (levels in the vertical and horizontal resolution in degrees), the thickness of the surface layer, and the marine biogeochemical components included in the ESM.

\begin{tabular}{|c|c|c|c|c|}
\hline Model & $\begin{array}{l}\text { Ocean } \\
\text { (level, zonal, meridional) }\end{array}$ & $\begin{array}{c}\text { First layer } \\
\text { thickness }(\mathrm{m})\end{array}$ & $\begin{array}{l}\text { Marine biogeochemical } \\
\text { components }\end{array}$ & References \\
\hline BCC-CSM1.1(m) & $40 \mathrm{lev}, 0.3-1,1^{\circ}$ & 10 & MOM4-L40 & Wu et al. (2013) \\
\hline CanESM2 & $40 \mathrm{lev}, 1.41,0.94^{\circ}$ & 10 & CMOC & Arora et al. (2013) \\
\hline CESM1-BGC & $60 \mathrm{lev}, 1.25,0.27-0.54^{\circ}$ & 10 & BEC & $\begin{array}{l}\text { Gent et al. (2011) } \\
\text { Lindsay et al. (2014) }\end{array}$ \\
\hline GFDL-ESM2G & $63 \mathrm{lev}, 0.3-1^{\circ}$ & 2 & TOPAZ2 & Dunne et al. (2013) \\
\hline HadGEM2-ES & $40 \mathrm{lev}, 0.3-1^{\circ}$ & 10 & Diat-HadOCC & $\begin{array}{l}\text { Collins et al. (2011) } \\
\text { Palmer and Totterdell (2001) }\end{array}$ \\
\hline MIROC-ESM & $44 \mathrm{lev}, 1.4,0.5-1.7^{\circ}$ & 2.5 & NPZD & $\begin{array}{l}\text { Watanabe et al. (2011) } \\
\text { Oschlies (2001) }\end{array}$ \\
\hline MPI-ESM-LR & $40 \mathrm{lev}, 1.5^{\circ}$ & 10 & HAMOCC5.2 & $\begin{array}{l}\text { Giorgetta et al. (2013) } \\
\text { Ilyina et al. (2013) }\end{array}$ \\
\hline MRI-ESM1 & $51 \mathrm{lev}, 0.5-1^{\circ}$ & 4 & NPZD & Yukimoto et al. (2012) \\
\hline NorESM1-ME & $53 \mathrm{lev}, 1.125^{\circ}$ & 10 & HAMOCC5.1 & $\begin{array}{l}\text { Assmann et al. (2010) } \\
\text { Tjiputra et al. (2013) }\end{array}$ \\
\hline
\end{tabular}

Table 2. Main characteristics of the marine biogeochemical components of the nine ESMs used in this study: list of nutrients limiting the phytoplankton growth and the number of explicitly represented phytoplankton and zooplankton groups.

\begin{tabular}{llll}
\hline Model & Nutrients & Phytoplankton & Zooplankton \\
\hline BEC & $5\left(\mathrm{NO}_{3}, \mathrm{NH}_{4}, \mathrm{PO}_{4}, \mathrm{SiO}_{4}, \mathrm{Fe}\right)$ & 3 (diatoms, nanophyto-, diazotrophs) & 1 \\
CMOC & $\mathrm{NO}_{3}$ & 1 & 1 \\
Diat-HadOCC & $4\left(\mathrm{NO}_{3}, \mathrm{NH}_{4}, \mathrm{SiO}_{4}, \mathrm{Fe}\right)$ & 2 (diatoms, non-diatoms) & 1 \\
HAMOCC5.1 & $4\left(\mathrm{NO}_{3}, \mathrm{PO}_{4}, \mathrm{SiO}_{4}, \mathrm{Fe}\right)$ & 1 & 1 \\
HAMOCC5.2 & $3\left(\mathrm{PO}_{4}, \mathrm{NO}_{3}, \mathrm{Fe}\right)$ & 1 & 1 \\
MOM4-L40 & $\mathrm{PO}_{4}$ & - & - \\
NPZD & $\mathrm{NO}_{3}$ & 1 & 1 \\
TOPAZ2 & $5\left(\mathrm{NO}_{3}, \mathrm{NH}_{4}, \mathrm{PO}_{4}, \mathrm{SiO}_{4}, \mathrm{Fe}\right)$ & 3 (diatoms, other eukaryotes, diazotrophs) & 1 \\
\hline
\end{tabular}

We note that the selection of $45^{\circ} \mathrm{S}$ as a boundary between the mid- and high-latitude SO could pose problems since the SO region has sophisticated dynamics, and, dependent on the models, the $45^{\circ} \mathrm{S}$ latitude could cut into regions of dominant carbon sources or sinks. To address this issue, we also perform additional analyses where we use a dynamic boundary separating the mid- and high-latitude Southern Ocean applying a surface density of $26.5 \mathrm{~kg} \mathrm{~m}^{-3}$. For instance, Séférian et al. (2012) apply this density line to separate the subtropical mode water (TMW; region of weak increase in future $\mathrm{CO}_{2}$ uptake) and the subantarctic model water (MW; region of strong increase in future $\mathrm{CO}_{2}$ uptake).

\section{Results}

\subsection{Inter-model contemporary and future $\mathrm{CO}_{2}$ uptake relationships}

The relationship between contemporary and future global $\mathrm{CO}_{2}$ uptake ( $R_{\text {mean }}^{\text {glb }}$ ) as simulated by the CMIP5 models is shown in the Fig. $2 \mathrm{a}$, and the relationships relating to $R_{\mathrm{cum}}^{\mathrm{glb}}$ are shown in Fig. 2b. Figure 2a shows that the models have positive correlation but weak linear relationships between the present and future $\mathrm{CO}_{2}$ uptake rate. However, the linear relationships become more pronounced for cumulative carbon

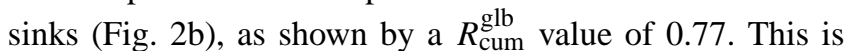
also consistent with Fig. 1, which shows that the inter-model spread in $\mathrm{CO}_{2}$ uptake evolves in a relatively similar manner into the future.

Next, for each region defined in Sect. 2.6 (as depicted in Fig. 3a), we computed the inter-model correlation coefficient metrics following Eqs. (3) and (4). The SO region yields the highest correlation coefficient as depicted in Fig. 3 with $R_{\text {cum }}^{\mathrm{SO}}=0.65$ and $R_{\text {mean }}^{\mathrm{SO}}=0.76$, in blue and red bars, respectively. Other regions remain weakly correlated with a correlation coefficient close to zero or under 0.40 for both correlation fields (TPa, TAt, Ind, NPa, NAt, and Arc regions). Only the $\mathrm{mSO}$ region reveals quite a strong negative correlation coefficient, with $R_{\text {mean }}^{\text {mSO }}=-0.55$. Nevertheless, in all regions except the $\mathrm{SO}$, the correlation coefficients are statistically insignificant at the $90 \%$ confidence level, while SO shows a statistical significance of over $99 \%$. For the remain- 

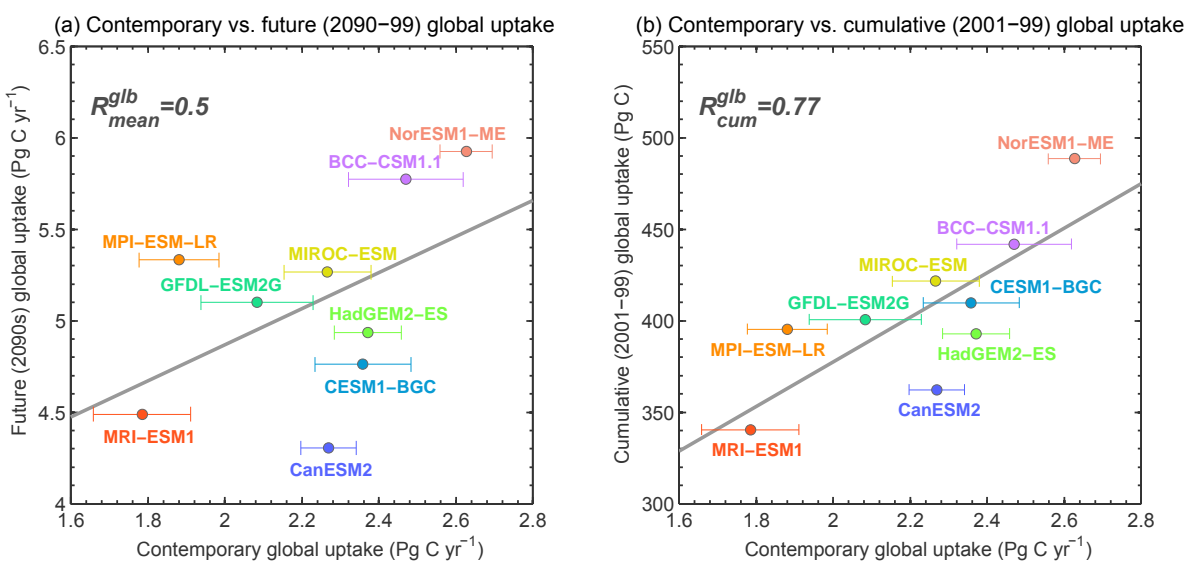

Figure 2. Global annual contemporary carbon uptake rate vs. (a) global future (2090-2099) carbon uptake and (b) cumulative global carbon uptake over 2001-2099. The straight gray lines show the best-fit linear regression across all models.

(a) Regional basin map

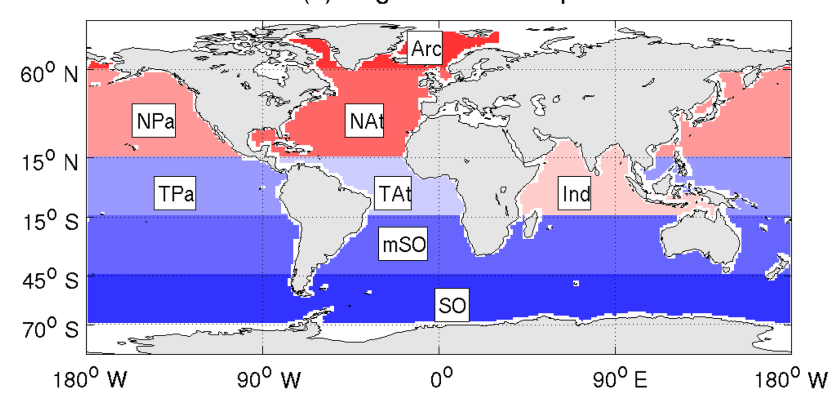

(b) Regional cumulative and annual mean correlation coef.

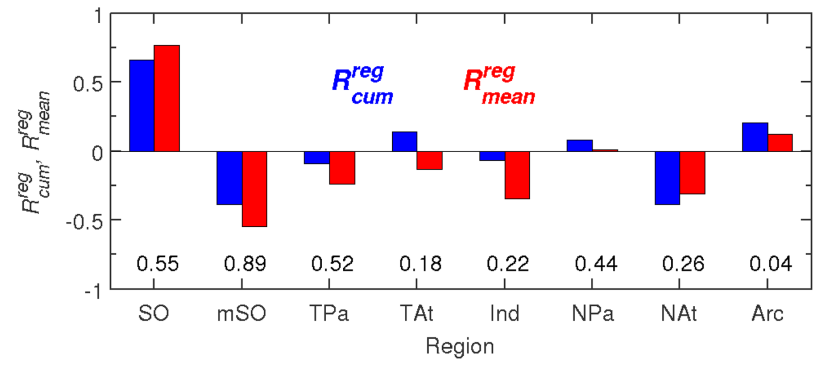

Figure 3. Panel (a): the eight regional ocean basins adopted in this study, defined according to different ocean basins and latitudinal lines of $70,45,15^{\circ} \mathrm{S}, 15$, and $60^{\circ} \mathrm{N}$, and (b) correlation coefficient between regional contemporary $\mathrm{CO}_{2}$ uptake rate with (red bars) future uptake rate in the 2090s and (blue bars) cumulative carbon uptake in the 21st century. The numbers over the $x$ axis on panel (b) represent the area of each region (in $10^{8} \mathrm{~km}^{2}$ ).

der of the analysis, we therefore combined the seven regions with an insignificant correlation coefficient into one new region: global ocean excluding $\mathrm{SO}$ (eSO).

Globally, for the annual oceanic $\mathrm{CO}_{2}$ uptake during the 2001-2010 period, all models except the NorESM1-ME are well within the range of the observation-derived estimate from Landschützer et al. (2014) of about $1.99 \pm$
$0.50 \mathrm{PgC}^{-1}$. The two highest uptake estimates are simulated by the BCC-CSM1.1(m) and NorESM1-ME models $\left(2.47 \pm 0.15\right.$ and $2.63 \pm 0.07 \mathrm{PgC} \mathrm{yr}^{-1}$, respectively), and the lowest uptake estimates come from the MPI-ESM-LR and MRI-ESM1 models $\left(1.88 \pm 0.10\right.$ and $1.78 \pm 0.13 \mathrm{PgCyr}^{-1}$, respectively).

Figure 4 depicts the inter-model relationships in the SO and eSO domains for $R_{\text {mean }}^{\mathrm{SO}}, R_{\text {mean }}^{\mathrm{eSO}}, R_{\text {cum }}^{\mathrm{SO}}$, and $R_{\text {cum }}^{\mathrm{eSO}}$. In SO, four models (BCC-CSM1.1, NorESM1-ME, MPI-ESMLR, and CESM1-BGC) overestimate the carbon uptake flux from the atmosphere to the ocean when compared with two independent observationally based estimates of about $0.15 \pm 0.12 \mathrm{PgC} \mathrm{yr}^{-1}$ (Landschützer et al., 2014) and $0.27 \pm$ $0.13 \mathrm{PgC} \mathrm{yr}^{-1}$ (Lenton et al., 2013); the latter is derived from Takahashi et al. (2009) data sets. The highest estimates are simulated by the BCC-CSM1 and NorESM1ME models at $1.03 \pm 0.09$ and $0.64 \pm 0.11 \mathrm{PgC} \mathrm{yr}^{-1}$, respectively. Two models (CanESM2 and MRI-ESM1) underestimate the flux, with the lowest estimate simulated by the CanESM 2 model, which is also the only model to simulate the Southern Ocean as a source of carbon to the atmosphere at about $-0.64 \pm 0.09 \mathrm{Pg} \mathrm{Cyr}^{-1}$ (Fig. 4a). Three other models (GFDL-ESM2G, MIROC-ESM, and HadGEM2-ES) project $\mathrm{CO}_{2}$ uptake within the two observationally based estimates.

Figure $4 \mathrm{a}$ and $\mathrm{c}$ illustrate the strong inter-model linear relationships between the contemporary $\mathrm{CO}_{2}$ uptake rate in the $\mathrm{SO}$ and the projected future uptake rate (Fig. 4a) and cumulated carbon uptake over the 21 st century (Fig. 4c). In the last decade of the 21 st century, the CMIP5 models project ocean carbon uptake rates ranging from 4.30 to $5.92 \mathrm{Pg} \mathrm{Cyr}^{-1}$. The cumulative oceanic $\mathrm{CO}_{2}$ uptake during the 21 st century is projected to be between 340.4 and $488.5 \mathrm{Pg} \mathrm{C}$.

Figure 4 also demonstrates the peculiarity of the Southern Ocean as compared to the rest of the world's ocean (eSO), where the contemporary $\mathrm{CO}_{2}$ uptake rate in the latter has a relatively strong negative correlation with $R_{\text {mean }}^{\mathrm{eSO}}=-0.52$ and $R_{\mathrm{cum}}^{\mathrm{eSO}}=-0.24$. To investigate the robustness of this cor- 

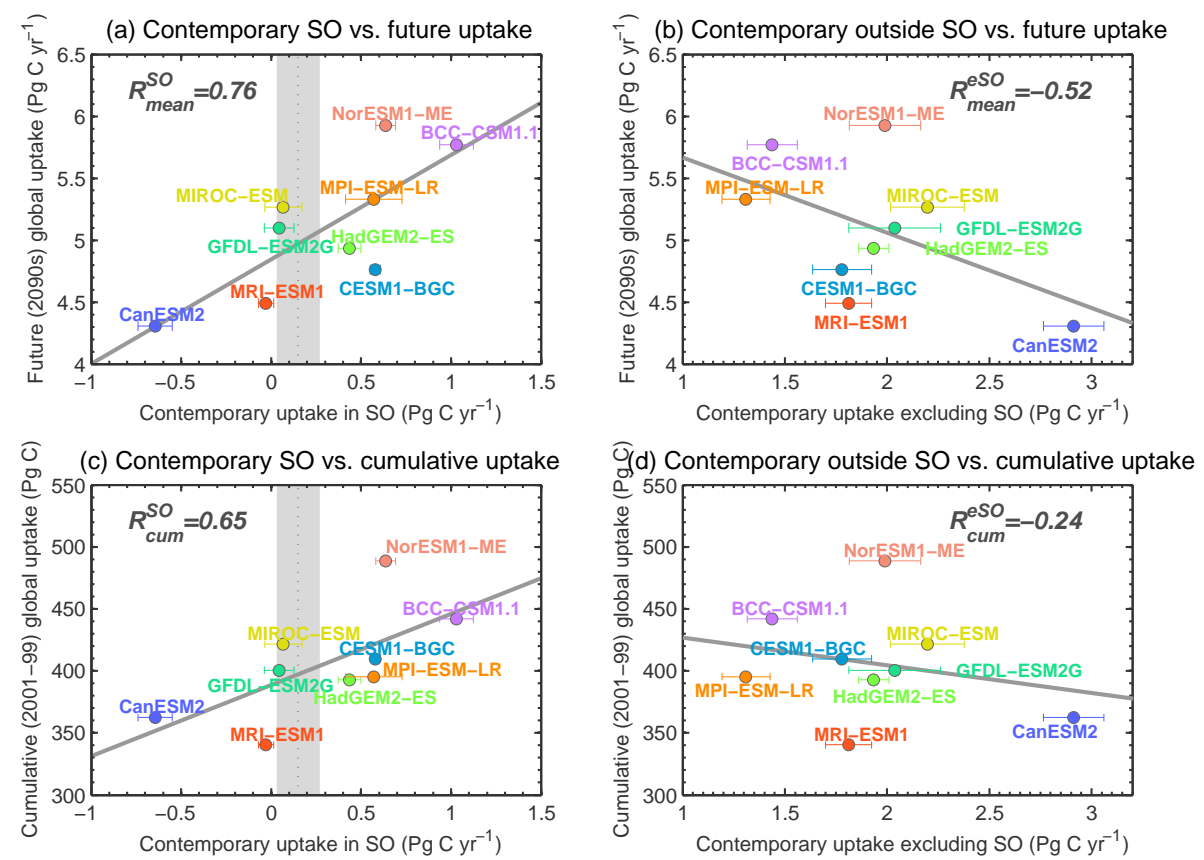

(e) Moving corr. coeff. (10-yr window) between regional $\mathrm{CO}_{2}$ uptake vs. cum. (2001-99) global uptake

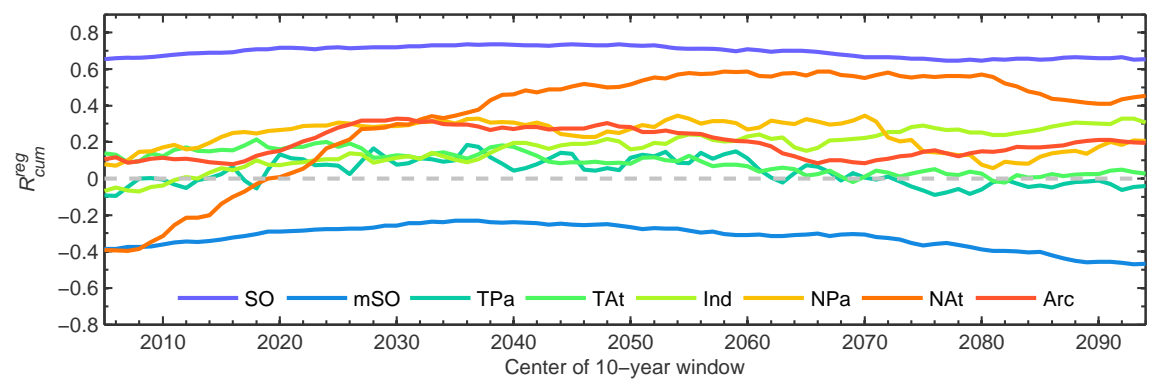

Figure 4. Annual contemporary carbon uptake rate vs. global uptake rate projected for the last decade of the 21st century by CMIP5 models in the (a) high-latitude Southern Ocean (SO) and (b) other ocean regions excluding the Southern Ocean (eSO). Annual contemporary carbon uptake rate vs. cumulative 21st-century carbon uptake projected by CMIP5 models in the (c) SO and (d) eSO. Panel (e): time series of correlation coefficient computed in a similar way as that in Fig. 3b (blue bars) for every decade between 2001 and 2099 . The straight gray lines in panels (a-d) show the best-fit linear regression across all models. Vertical shades on panels (a, c) depict observation-based estimates (Landschützer et al., 2014).

relation coefficient with time, we computed $R_{\text {cum }}^{y}$ for all of the original eight regional basins for all 10-year windows between 2001 and 2099 (shown in Fig. 4e). The SO region is shown to have a consistently strong positive correlation coefficient across time with $R_{\text {cum }}^{\text {SO }}$ values of $0.69 \pm 0.04$. Other regions have more pronounced temporal variations, particularly the North Atlantic (NAt), which goes from a negative correlation in the early 21 st century $(-0.39)$ to a positive correlation after 2020; the latter increases to 0.59 . However, the correlation in the NAt remains statistically insignificant at $90 \%$ of confidence level.

As stated in Sect. 2.6, we also computed the correlation coefficient metrics for the SO region using a dynamic boundary (instead of a fixed $45^{\circ} \mathrm{S}$ latitude) along the surface water with a density of $26.5 \mathrm{~kg} \mathrm{~m}^{-3}$. Figure $5 \mathrm{c}$ illustrates the model-dependent dynamic boundaries as simulated for $\mathrm{Au}$ gust 2005. Figure 5a and $\mathrm{b}$ show that the linear inter-model relationships remain strong (correlation coefficient of at least 0.76 ) when the dynamic boundary is used, suggesting that the inter-model relationships in the $\mathrm{SO}$ are relatively robust.

\subsection{Carbon uptake evolution in the Southern Ocean}

In this section, we examine why the SO has the highest $R_{\text {mean }}^{\text {SO }}$ and $R_{\text {cum }}^{\mathrm{SO}}$ relative to the other regions. Only seven out of the nine models previously used to establish the correlations are used; the BCC-CSM1 and MIROC-ESM models are excluded because they do not provide the monthly ALK and DIC fields needed for the uptake $e_{\text {eff }}$ analysis. The remaining models are CanESM2, CESM1-BGC, GFDL-ESM2G, HadGEM2-ES, MPI-ESM-LR, MRI-ESM1, and NorESM1- 
(a) Contemporary SO vs. future uptake

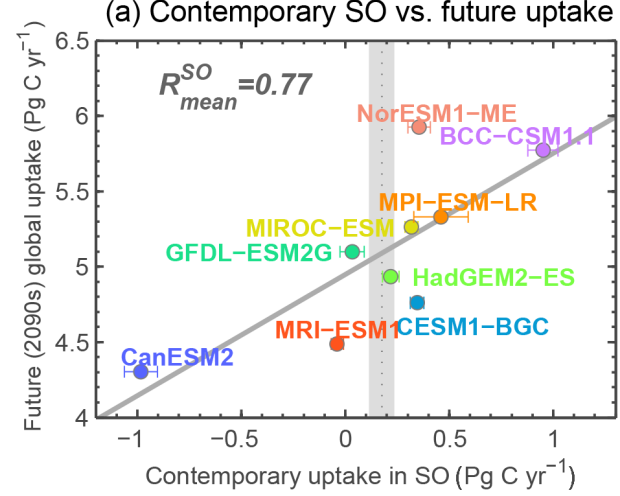

(b) Contemporary SO vs. future uptake

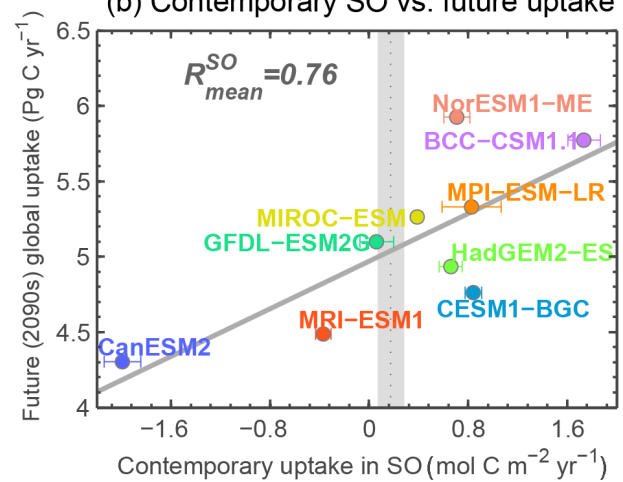

(c) SAMW model boundaries

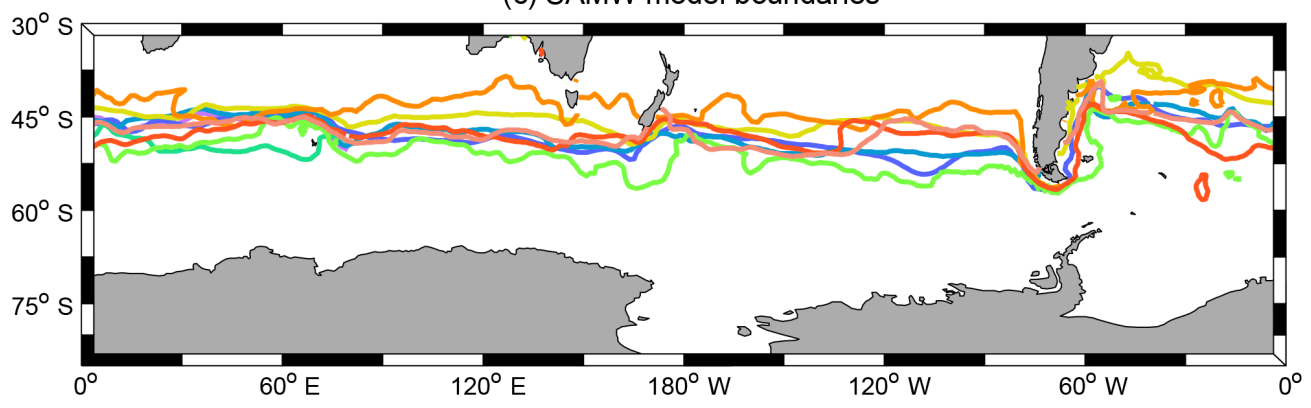

Figure 5. Annual contemporary carbon uptake vs. global uptake rate projected for the last decade of the 21 st century by CMIP5 models. Here the SO is defined using dynamic boundaries separated by a surface water density of $26.5 \mathrm{~kg} \mathrm{~m}^{-3}$. Panels (a) and (b) show the contemporary SO carbon uptake on the $x$ axes in $\mathrm{PgC} \mathrm{yr}^{-1}$ and $\mathrm{mol} \mathrm{C} \mathrm{m}^{-2} \mathrm{yr}^{-1}$, respectively. Panel (c) illustrates the $26.5 \mathrm{~kg} \mathrm{~m}^{-3}$ density lines that separate the MW from the TMW for the month of August 2005 as simulated by the different models (same color convention as in $\mathbf{a}$ and $\mathbf{b}$ ).

ME. Figure 6 shows the time series anomalies (relative to the year 2001) of $\mathrm{CO}_{2}$ uptake, net primary production (NPP),

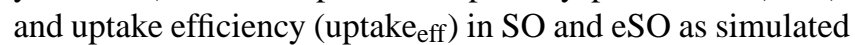
by the CMIP5 models.

There is a general increase in $\mathrm{CO}_{2}$ uptake for both $\mathrm{SO}$ and eSO, as would be expected from the increasing atmospheric $\mathrm{CO}_{2}$ concentrations under the RCP8.5 scenario. However, in SO (except for the CESM1-BGC model) the simulated uptake rates steadily increase towards the end of the 21 st century, and the multi-model mean increases to $1.2 \pm 0.3 \mathrm{PgC} \mathrm{yr}^{-1}$ higher than in the present day (Fig. 6a). The CESM1-BGC model simulates stabilization of $\mathrm{CO}_{2}$ uptake during the last 2 decades of the 21 st century. In the other regions (Fig. 6b), the multi-model mean reaches a saturation point of $1.9 \pm 0.4 \mathrm{PgC} \mathrm{yr}^{-1}$ in the $2070 \mathrm{~s}$ before the uptake strengths go down to $1.5 \pm 0.4 \mathrm{PgC} \mathrm{yr}^{-1}$ in 2100 . This "peak and decline" pattern is consistently shown in all models analyzed here.

The unique SO region benefits from the strong link between deep and surface ocean through the southern upwelling (Sallée et al., 2013a). Earlier studies analyzing the previous generation of ESMs also demonstrated that this region will be an important sink of future atmospheric $\mathrm{CO}_{2}$ although the efficiency of the sink may decrease (Roy et al.,
2011). The increasing $\mathrm{CO}_{2}$ sink in the $\mathrm{SO}$ was shown to be associated with a reduction in the fractional ice coverage which alleviates the light limitation on photosynthesis and increases in surface ocean temperature, both of which would increase the phytoplankton growing season.

A global mean decrease in NPP of about $-3.12 \pm$ $3.54 \mathrm{PgC} \mathrm{yr}^{-1}$ is projected by the CMIP5 models, predominantly attributed to the increase in surface temperature leading to stronger stratification and hence reducing the nutrient supply to the surface ocean through vertical mixing (Bopp et al., 2013). The large differences between the structure of the ecosystem models of the CMIP5 models no doubt contribute to the large inter-model uncertainty. For example, the GFDL-ESM2G and MRI-ESM1 models simulate global annual NPP estimates which differ by more than a factor of 2 at 66.7 and $25.9 \mathrm{PgC} \mathrm{yr}^{-1}$, respectively (not shown), and are outside of the multi-model standard deviation for the NPP estimates. The MRI-ESM1 model considers only one nutrient limitation and simulates only one type of phytoplankton, while the GFDL-ESM2G model uses a more sophisticated ecosystem module with five types of nutrients and three classes of phytoplankton (Table 2). However, this alone is insufficient to determine the reason why the GFDL-ESM2G NPP is so strong. On the other hand, the MPI-ESM-LR NPP 
(a) $\mathrm{CO}_{2}$ uptake anomaly in $\mathrm{SO}$

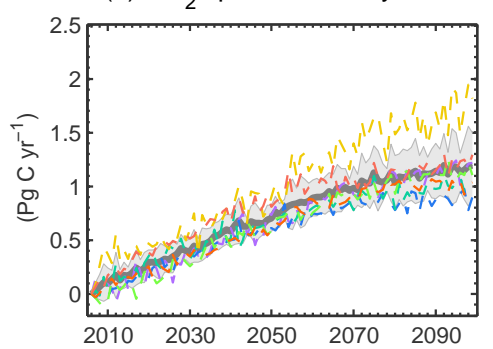

(c) NPP anomaly in SO

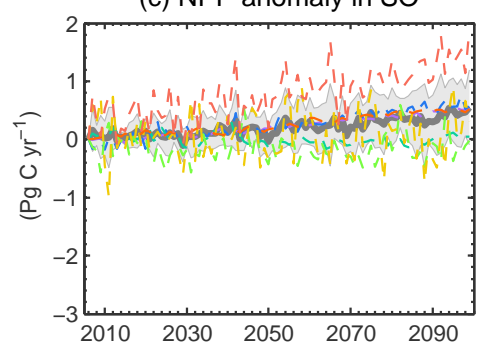

(e) uptake ${ }_{\text {eff }}^{S O}$ anomaly

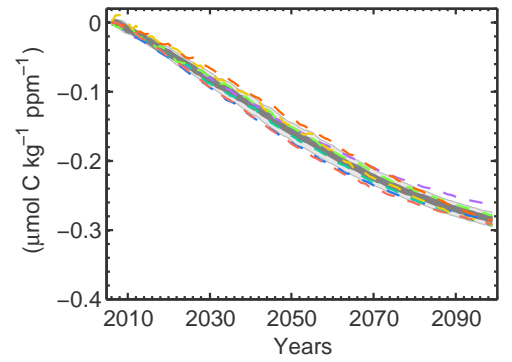

(b) $\mathrm{CO}_{2}$ uptake anomaly outside $\mathrm{SO}$

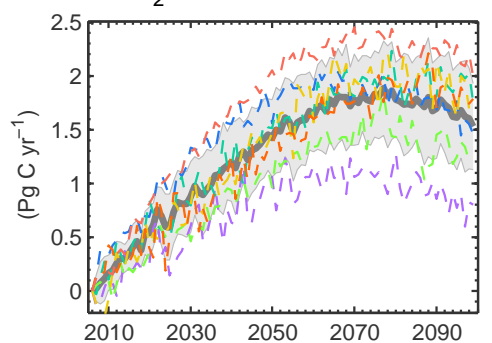

(d) NPP anomaly outside SO

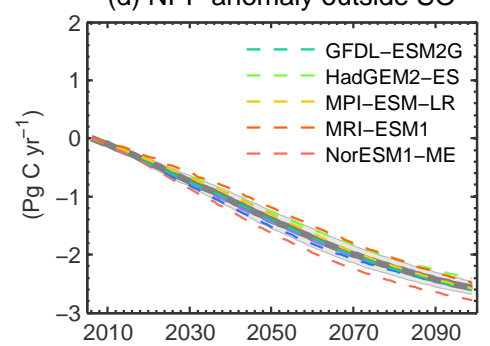

(f) uptake $e_{\text {eff }}^{e S O}$ anomaly

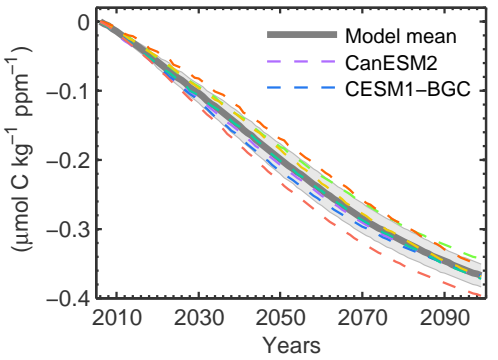

Figure 6. Time series of anomalies (relative to the year 2001) of annual mean (a) carbon uptake, (c) net primary production, and (e) carbon uptake efficiency in the Southern Ocean. Panels (b), (d), and (f) also show the same fields as the panels on the left but for the ocean region outside of SO. Thick gray lines represent the inter-model mean, with gray shadings representing \pm 1 standard deviation of inter-model variations.

is at the low end of the inter-model range. Inter-model variations in the physical and biogeochemical interaction important for the surface primary productivity, such as irradiance and upwelling, should be analyzed further to seek to address this question. This, however, is beyond the scope of the present study.

Figure 6c-d show the NPP anomalies relative to 2001 in the SO and eSO regions through the 21st century, highlighting that surface primary production in $\mathrm{SO}$ is either stable or weakly increasing by roughly $0.5 \pm 0.3 \mathrm{PgC}^{-1}$ at the end of this century, while it is clearly decreasing in the other regions (by $-2.6 \pm 0.1 \mathrm{PgC} \mathrm{yr}^{-1}$ ). This is consistent with findings by Laufkötter et al. (2015), who show that the NPP increase in the SO is predominantly attributed to the weakening temperature limitation for phytoplankton growth projected in the future. They also indicate that, despite the inter-model agree- ment in long-term trend, the regional inter-model variation is substantial.

In SO, steady biological production may also be responsible for maintaining low $p \mathrm{CO}_{2}$ in the summer and keeping a higher buffer capacity than in the other regions (Hauck and Völker, 2015). The two last panels of Fig. 6 show the anomaly of uptake eff (Sect 2.4 for definition), which is expected to decrease as the Revelle Factor increases under future high ambient atmospheric $\mathrm{CO}_{2}$ concentrations (Heinze et al., 2015). Nevertheless, the decreasing trend is weaker in the SO than the eSO region at $-0.28 \pm 0.01$ vs. $-0.37 \pm$ $0.02 \mu \mathrm{mol} \mathrm{kg}{ }^{-1} \mathrm{ppm}^{-1}$ respectively by the year 2099 . Indeed, for the same change in $p \mathrm{CO}_{2}$ and roughly the same Revelle Factor change, the SO experiences a smaller change in DIC (not shown), indicating a unique process occurring in the high-latitude SO. Deep winter mixing at polar regions is very efficient in transporting the anthropogenic carbon from 
(a) Contemporary monthly $\mathrm{fgCO}_{2}$

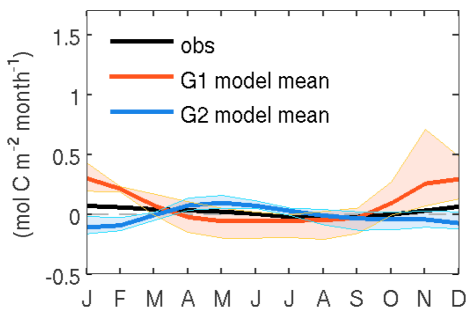

(c) Contemporary monthly NPP

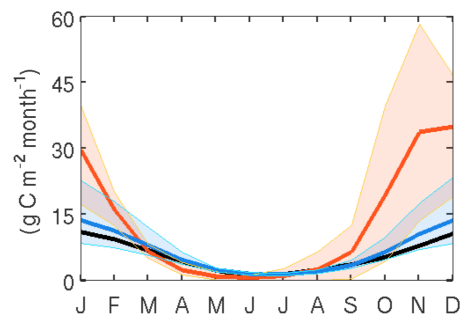

(e) Contemporary SST anomalies

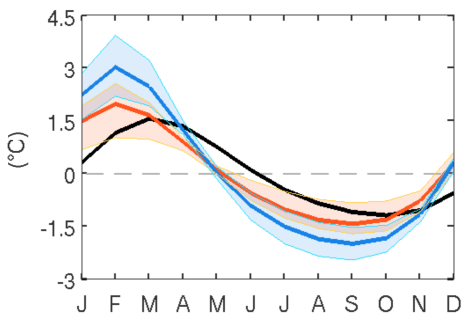

(b) Future monthly $\mathrm{fgCO}_{2}$

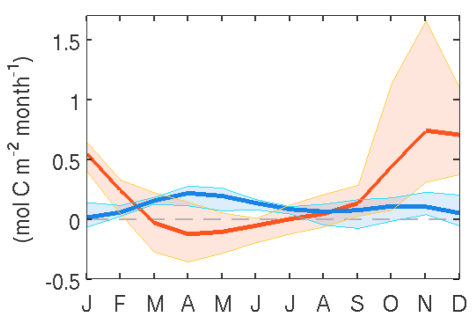

(d) Future monthly NPP

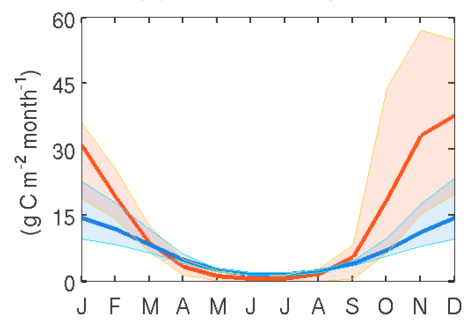

(f) Future SST anomalies

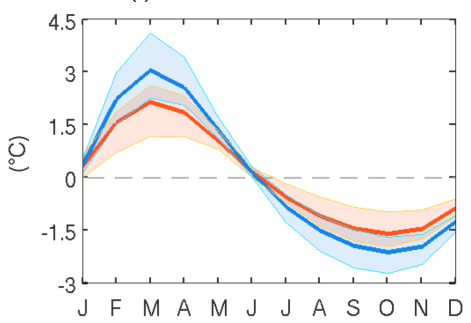

Figure 7. Seasonal cycle of (a-b) carbon flux, (c-d) NPP, and (e-f) SST anomalies for the Southern Ocean region simulated by CMIP5 models for the 2001-2010 (left panels) and 2090-2099 (right panels) decades. The red (blue) shadings represent the range of G1 (G2) models that simulate anomalously strong (weak) carbon uptake (see also text in Sect. 3.3). The colored lines represent the mean of the respective model groups, black lines represent the observational estimate adopted from Landschützer et al. (2014) for $\mathrm{CO}_{2}$ uptake and SST anomaly, and the NPP was taken from SeaWiFS data as described in Nevison et al. (2015).

surface to depth, resulting in an increase in uptake efficiency (Marinov et al., 2007). Moreover, the increase in the meridional temperature gradient from the tropic, to the high latitudes projected in the future could lead to an enhancement of the Antarctic Circumpolar Current via a stronger wind stress at the surface (Gillett and Fyfe, 2013). As a result, this could translate into enhancement in intermediate water formation and more efficient transport of anthropogenic carbon from the surface into depth.

The steady increase in carbon uptake in the SO region could be the reason for the strong correlation of this region with future global sinks (Sect. 3.1 and Fig. 4a). In the next subsections, we therefore focus on analyzing the mechanism for ocean uptake in the SO region as simulated by the different models.

\subsection{Inter-model division in the Southern Ocean carbon uptake}

Figure $4 \mathrm{a}-\mathrm{b}$ show that the CMIP5 models exhibit diverse contemporary carbon uptake sinks in $\mathrm{SO}$, from an outgassing of $-0.64 \pm 0.09 \mathrm{Pg} \mathrm{C} \mathrm{yr}^{-1}$ (CanESM2) to an uptake of $1.03 \pm$ $0.09 \mathrm{PgC} \mathrm{yr}^{-1}$ (BCC-CSM1.1). To investigate the mechanisms driving the inter-model heterogeneity, we compute the carbon uptake on a seasonal timescale and compare it to estimates derived from observations (Landschützer et al., 2014).

We divided the seven CMIP5 models into two groups. The first group (hereafter referred to as "G1") represents those that simulate an anomalously stronger annual $\mathrm{CO}_{2}$ uptake rate in the $\mathrm{SO}$ as compared to the observationally based estimates and consists of the CESM1-BGC, HadGEM2ES, MPI-ESM-LR, and NorESM1-ME models. The second group (hereafter referred as "G2") comprises models that simulate anomalously weaker $\mathrm{CO}_{2}$ uptake, consisting of the CanESM2, GFDL-ESM2G, and MRI-ESM1 models. Figure 7 shows the inter-model mean and spread of these two 
groups in their projections of the seasonal cycle of carbon fluxes, NPP, and anomalies of SST for both the contemporary (2001-2010) and future (2090-2099) periods.

Figure 7 illustrates that the G1 models have nearly the opposite seasonal cycle to the G2 models. The G1 models (Fig. 7a, red lines) simulate a strong mean ocean $\mathrm{CO}_{2}$ uptake in December-January of about $0.30 \mathrm{~mol} \mathrm{C} \mathrm{m}^{-2} \mathrm{month}^{-1}$, which has the same direction as, but is more than 4 times stronger in magnitude than, the observation-based estimate of $0.07 \mathrm{~mol} \mathrm{C} \mathrm{m}^{-2}$ month $^{-1}$. This overestimation corresponds to the period of the highest NPP, where the G1 model means simulate an NPP maximum more than 3 times stronger than the observations: 35 compared to $11 \mathrm{~g} \mathrm{C} \mathrm{m}^{-2}$ month $^{-1}$, respectively (Fig. 7c, black and red lines). Moreover, the SST anomaly during this 2-month period has a negligible effect on the $\mathrm{CO}_{2}$ flux; there is no significant change in carbon flux occurring when the SST anomaly increases from +0.3 to $+1.5^{\circ} \mathrm{C}$ (Fig. 7e, red line). This highlights that the biological activity in $\mathrm{G} 1$ models is the primary driver for the $\mathrm{CO}_{2}$ flux seasonal cycle in SO during the highproductivity season, while the impact of the seasonal temperature on the surface $p \mathrm{CO}_{2}$ appears to play only a secondary role (Takahashi et al., 2002).

In contrast to the G1 models, G2 models (Fig. 7, blue lines) simulate strong outgassing during the summertime with a negative $\mathrm{CO}_{2}$ flux of nearly $-0.10 \mathrm{molC} \mathrm{m}^{-2}$ month $^{-1}$. This is in disagreement with the observation-based estimates and is predominantly driven by the SST changes. The magnitude of the SST anomaly from the G2 models is 2 times stronger than the observations, whereas the NPP cycle is similar in amplitude. The rapid warming and cooling of SST simulated in the $\mathrm{G} 2$ models during the spring and fall seasons lead to a higher and lower surface $p \mathrm{CO}_{2}$, respectively. As a result, the $\mathrm{G} 2$ models simulate strong $\mathrm{CO}_{2}$ uptake during the fall season, which also implies that the solubility pump is a primary driver.

During the austral winter, in August, observationbased estimates show a maximum outgassing, roughly -0.03 mol C m$^{-2}$ month $^{-1}$ (Fig. 7a, black line). G1 models simulate the same mechanism at this period but the maximum outgassing is reached earlier in May-June instead of August. Concurrently, G1 models simulate a minimum of NPP at this time, pushing up the $p \mathrm{CO}_{2}$ at the surface. Thus, the SO turns into a source of $\mathrm{CO}_{2}$ for the atmosphere despite the SST anomaly of about $-0.6^{\circ} \mathrm{C}$, which would tend to push the $p \mathrm{CO}_{2}$ in the opposite direction. The same shift appears for G2 models but for an opposite $\mathrm{CO}_{2}$ flux seasonal cycle, with a maximum uptake in May of nearly $0.10 \mathrm{~mol} \mathrm{C} \mathrm{m}^{-2}$ month $^{-1}$. The NPP is twice as strong in May-June for the G2 models than for the G1 models at 1.5 vs. $0.6 \mathrm{~g} \mathrm{C} \mathrm{m}^{-2}$ month $^{-1}$, respectively. This, in addition to a stronger magnitude of SST anomaly, leads to a $\mathrm{CO}_{2}$ uptake in April-June being projected by the $\mathrm{G} 2$ models as depicted in Fig. 7a (blue line).
Figure 8 illustrates the mean spatial variation in $\mathrm{CO}_{2}$ uptake for each season from Landschützer et al. (2014) and as simulated by the G1 and G2 models during the contemporary period. In the G1 models, the seasonal cycle that is too strong as compared to the observation-based estimates occurs throughout most parts of the SO, especially during October-December and January-March, with considerably stronger carbon sinks found in the south of the circumpolar current. Between 50 and $60^{\circ} \mathrm{S}$, the outgassing in G1 models is noticeably stronger during April-June and JulySeptember. In the G2 models, the largest source of bias during October-December and January-March when compared to the Landschützer et al. (2014) estimates is found in the Atlantic and Indian sectors of the SO where the models simulate a relatively uniformly strong outgassing.

Future period simulations (Fig. 7, right panels) show that the seasonal phase in the carbon flux will be relatively similar, but the amplitude will grow considerably as compared, to the current seasonality. The distinctions in NPP and SST seasonal cycle between G1 and G2 models are also maintained. Therefore, the bias in the present-day seasonal phase of $\mathrm{CO}_{2}$ fluxes is projected to persist toward the end of the 21 st century. We note that there is a 1-month shift in simulated SST anomaly seasonal cycle where a maximum SST anomaly appears in March instead of February.

\subsection{Drivers for the Southern Ocean carbon uptake}

Following Eq. (1) in the methods section, we decomposed the $p \mathrm{CO}_{2}$ seasonal cycle anomalies into four drivers: DIC, ALK, SST, and SSS for both the contemporary and future periods (shown in Fig. 9). The SSS-induced variations are not shown because the magnitude is negligible relative to the other variables. As with the previous subsection, we focused our analysis on the two contrasting model groups (G1 and G2). The amplitude of $p \mathrm{CO}_{2}$ from the $\mathrm{G} 1$ (Fig. 9a, red line) overestimates the Landschützer et al. (2014) estimations. Nevertheless, it fits closer with later measurements from Merlivat et al. (2015), though they estimated the sea-air carbon flux only from a section of the Southern Ocean where $p \mathrm{CO}_{2}$ anomaly amplitudes can reach roughly $120 \mu \mathrm{atm}$. In both groups as well as the observation-based estimates, the SST- and ALKinduced $p \mathrm{CO}_{2}$ anomalies are generally in phase with each other and they are the opposite of the DIC-induced variability.

The DIC-induced $p \mathrm{CO}_{2}$ anomaly from the $\mathrm{G} 1$ models simulates a minimum in January instead of March, a 2-month shift as compared to the values derived from Landschützer et al. (2014). The G1 models, which simulate anomalously strong SO carbon uptake, generally simulate too low a surface $p \mathrm{CO}_{2}$ during December-January (an anomaly of $-40 \mu$ atm; Fig. 9a, red line) due to the NPP that is too strong (Fig. 7c, red line). The driving parameter seems to be the DIC at the water surface $(-38$ to $-64 \mu$ atm of anomalies in December-January). Thus, DIC consumption by the phyto- 

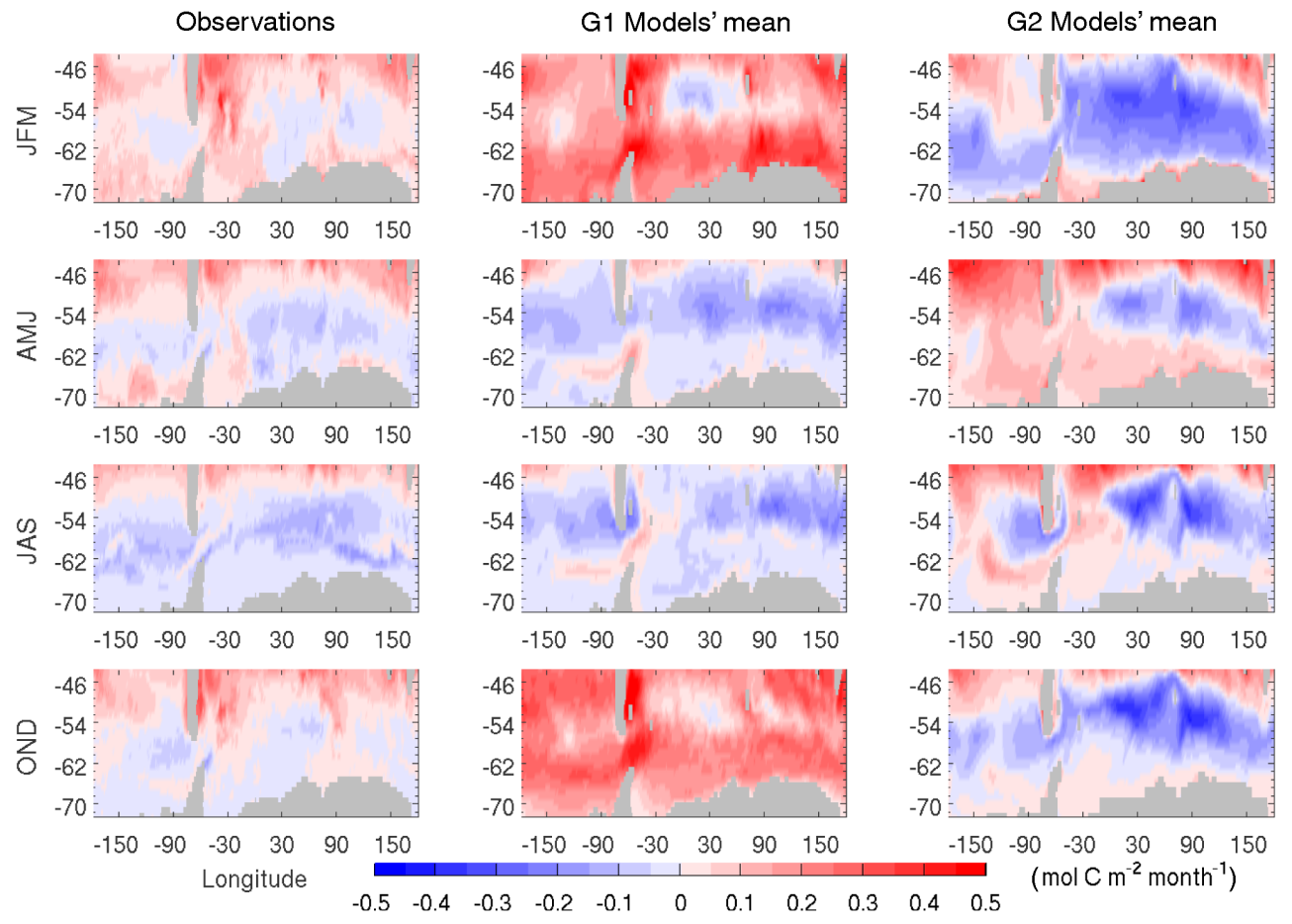

Figure 8. Contemporary (2001-2010) seasonal mean of air-sea $\mathrm{CO}_{2}$ fluxes from (first column) observations-based estimates of Landschützer et al. (2014), (second column) G1 models, and (third column) G2 models. Each row of panels depicts values for different seasons (JFM, AMJ, JAS, and OND).

plankton via photosynthesis confirms the importance of biological activity for carbon uptake in this group of models during this high-productivity period. The G2 models project nearly the same amplitude as that derived from observations but depict an opposite phase for carbon uptake. Figure 9 shows that $\mathrm{G} 2$ models simulate surface $p \mathrm{CO}_{2}$ during December-January that is, anomalously, too strong, of roughly 7 to $12 \mu$ atm (Fig. 9c, blue line). There, the driving parameters are the SST and alkalinity with anomalies of about 38 and $19 \mu \mathrm{atm}$ in January, respectively. Indeed, these two components tend to push up the $p \mathrm{CO}_{2}$ at the surface in the summer season (December-March) and present also a 1-month shift as compared to the values derived from observations (Fig. 9c, gray squares and circles).

The future simulations accentuate even more the $p \mathrm{CO}_{2}$ seasonal cycles for the G1 models (Fig. 9b, red line). The amplitude of this seasonal cycle approximately doubles in 2090-2099 relative to 2001-2010 (i.e., the standard deviation increases from 24.5 to $50.3 \mu \mathrm{atm}$ ), mostly due to the DICinduced variability (Fig. 9b, red triangles). The amplitudes of the SST-induced and ALK-induced variability are projected to double as well; however, their combined magnitude is still weaker than DIC-induced variability. The G2 models maintain roughly the same amplitude of total $p \mathrm{CO}_{2}$ through the 21 st century (Fig. 9d, blue line), though the $p \mathrm{CO}_{2}$-induced components also increase by a factor of 2 . Nevertheless, the DIC-induced seasonal cycle of the G2 models, conversely to the $\mathrm{G} 1$, is of about the same order of magnitude as the SST-induced seasonal cycle, thus balancing the change in the $p \mathrm{CO}_{2}$.

\section{Discussion}

The ocean plays an instrumental role in buffering the increasing atmospheric $\mathrm{CO}_{2}$ concentration and the ongoing climate change. In this study, for the first time, we evaluate the relationships between present-day regional ocean carbon sinks with future cumulative carbon sinks over the 21 st century under the high $\mathrm{CO}_{2} \mathrm{RCP} 8.5$ scenario as simulated by a suite of fully interactive CMIP5 ESMs. The SO is found to be a good predictor for future global carbon uptake. We therefore examined the representation of oceanic carbon uptake and its future evolution in the SO. Specifically, we assess the model capability to simulate the observed seasonal $p \mathrm{CO}_{2}$ cycle for the present-day period.

With respect to the annual mean $\mathrm{CO}_{2}$ uptake in the Southern Ocean, Jiang et al. (2014) evaluate a set of CMIP5 models but from different simulations, i.e., with prescribed atmospheric $\mathrm{CO}_{2}$ concentrations, and over a slightly smaller domain $\left(56-62^{\circ} \mathrm{S}\right)$. Despite these differences, our present findings are very much comparable to the prior study, with the CanESM2 and GFDL-ESM2G models simulating net outgassing and close to neutral $\mathrm{CO}_{2}$ fluxes. By contrast, the HadGEM2-ES and MPI-ESM-LR were shown to have 
(a) Present $\mathrm{pCO}_{2}$ anomalies from $\mathrm{G} 1$ models

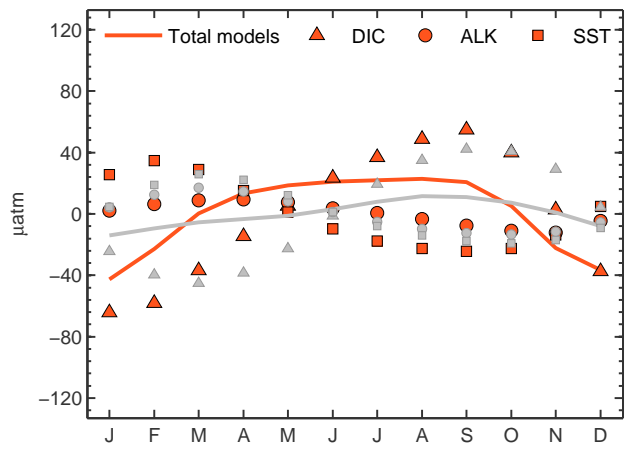

(c) Present $\mathrm{pCO}_{2}$ anomalies from $\mathrm{G} 2$ models

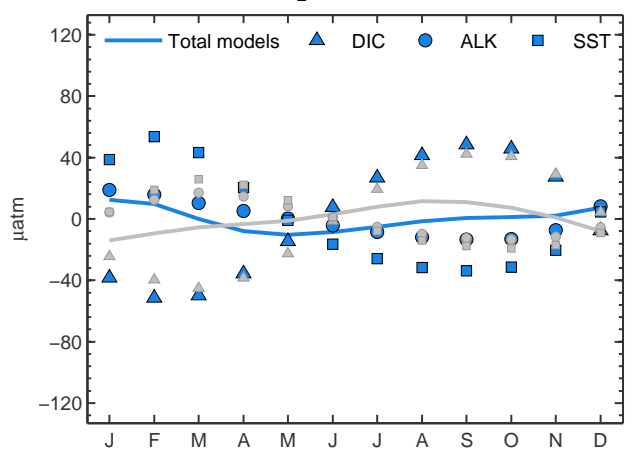

(b) Future $\mathrm{pCO}_{2}$ anomalies from $\mathrm{G} 1$ models

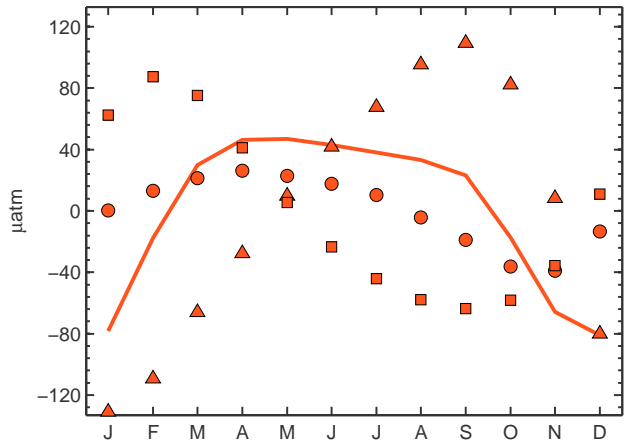

(d) Future $\mathrm{pCO}_{2}$ anomalies from $\mathrm{G} 2$ models

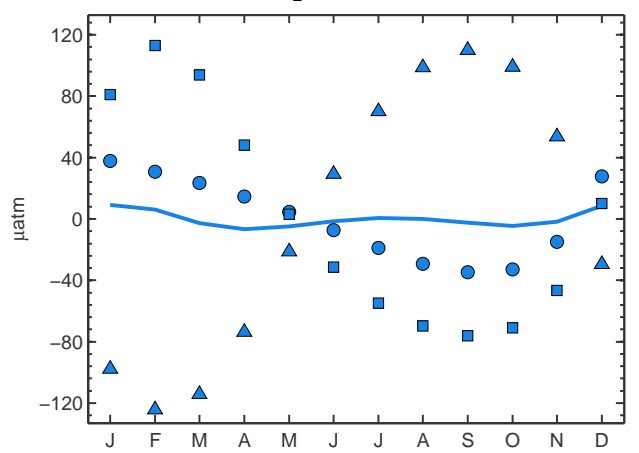

Figure 9. Anomalies of decomposed $p \mathrm{CO}_{2}$ components in the Southern Ocean for the 2001-2010 (left panels) and future 2090-2099 (right panels) periods: (a, b) overestimating models; $(\mathbf{c}, \mathbf{d})$ underestimating models. Values shown are from multi-model mean. The gray lines and markers are estimates derived from observations according to Landschützer et al. (2014).

relatively stronger carbon sinks, especially during austral summer. For the 2001-2010 period, only one model (MRIESM1, $~ 362 \mu \mathrm{atm})$ simulates a mean surface $p \mathrm{CO}_{2}$ in the SO that is lower than the observed $\sim 364 \mu$ atm; the majority of models simulate a stronger mean carbon sink than the observational estimate. This indicates the need to consider the seasonal cycle when evaluating carbon uptake projections in the SO.

Jiang et al. (2014) also examine the CMIP5 models' simulated $p \mathrm{CO}_{2}$ seasonal cycle in the Drake Passage as compared to shipboard measurements. They show that the $p \mathrm{CO}_{2}$ seasonal cycle in this confined domain is representative of the broader circumpolar region. Our analysis using Landschützer et al. (2014) data further indicates that the $p \mathrm{CO}_{2}$ seasonal cycle in the $\mathrm{SO}$ region is reasonably homogeneous in phase, with the maximum $p \mathrm{CO}_{2}$ in austral winter (August) and the minimum in summer (January), as illustrated in Figs. 7 and 9. We show that most models simulate a larger seasonal $p \mathrm{CO}_{2}$ amplitude than the observation-based estimates. Despite overestimating the mean carbon sinks, both HadGEM2-ES and MPI-ESM-LR reproduce the seasonal phase of the data. The MPI-ESM-LR simulates carbon uptake in the early spring period that is too strongly biologically mediated, consistent with the anomalously strong late winter mixing (August-September) (Jiang et al., 2014; Sallée et al., 2013b), which causes the required nutrients to upwell to fuel biological production. The GFDL-ESM2G, one of the two models that simulate carbon sinks closest to the data-based estimate, simulates the opposite $p \mathrm{CO}_{2}$ seasonal phase, which is largely attributed to the bias in absolute values and amplitude of SST seasonal cycle. None of the CMIP5 models analyzed here are able to reproduce the observed seasonal cycle and annual mean carbon sinks within the uncertainty range in the SO. This highlights the difficulty in simulating the correct variability in hydrography and biogeochemistry in this region.

Based on the linear inter-model relationship presented in this study, the GFDL-ESM2G, MIROC-ESM, and HadGEM2-ES models simulate contemporary $\mathrm{CO}_{2}$ fluxes in the SO closest to the observationally based estimate (see, for example, Fig. 5a) and therefore are likely to have more credibility with regard to their future projections. Nevertheless, from our seasonal cycle analysis, it is not clear if these models simulate the observed mechanisms governing the $\mathrm{CO}_{2}$ fluxes. According to Landschützer et al. (2015), the nonthermal component of the $p \mathrm{CO}_{2}$ variation is an important driver 


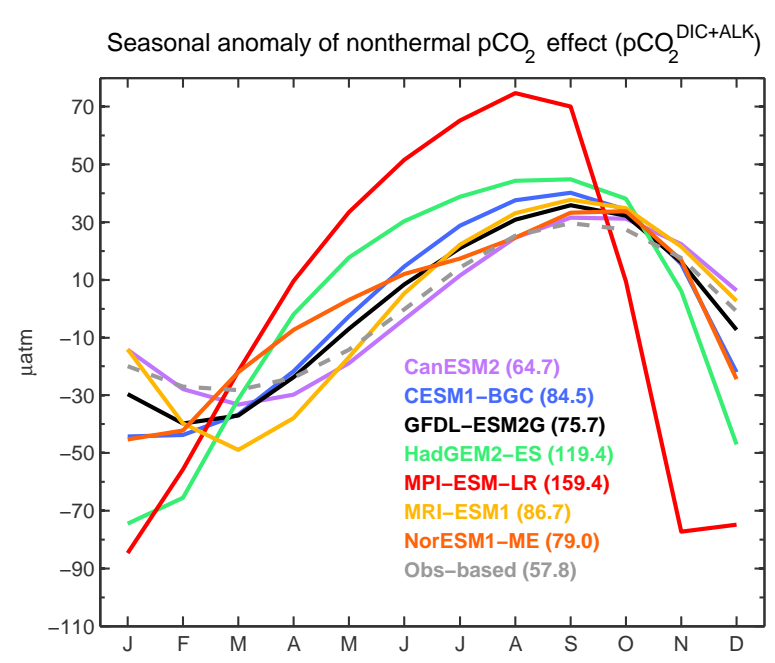

Figure 10. Anomalies of nonthermal $p \mathrm{CO}_{2}$ seasonal cycle, $\left(p \mathrm{CO}_{2}^{\mathrm{DIC}+\mathrm{ALK}}\right)$ as simulated by seven ESMs for the 2001-2010 period. The gray dashed line indicates the observation-based estimate of the $p \mathrm{CO}_{2}^{\mathrm{DIC}+\mathrm{ALK}}$ seasonal cycle. The numbers within the parentheses represent the amplitude for each model as well as for the observation-based estimate.

for the long-term $\mathrm{CO}_{2}$ fluxes in the SO. Figure 10 shows the seasonal anomaly of a nonthermal $\mathrm{CO}_{2}$ seasonal cycle in the SO from models and observation-based estimate. The CanESM2 and GFDL-ESM2G simulate comparable amplitude and seasonal phase with the observation-based estimate, but the former model has anomalously high surface $p \mathrm{CO}_{2}$ (i.e., it simulates a net source of $\mathrm{CO}_{2}$ to the atmosphere in the SO). Taking this as an additional constraint, our analysis suggests that the GFDL-ESM2G performs best in capturing the observed $\mathrm{CO}_{2}$ fluxes in the Southern Ocean.

In their model study applying an ad hoc parameterization of wind stirring, Rodgers et al. (2014) demonstrate that changes in wind stirring have a large impact on the mean carbon uptake and seasonal cycle phasing in the SO (south of $45^{\circ} \mathrm{S}$ ). They show that resultant changes in the seasonal onset of stratification influence both entrainment and the biological pump. Furthermore, Sallée et al. (2013b) identify the annual mean freshwater flux as the primary source of error for the SO mixed layer depth in CMIP5 models. This uncertainty arises from the lack of accurate estimates of buoyancy fluxes from observations in the region.

In the $\mathrm{SO}$, the $\mathrm{CO}_{2}$ flux and its evolution in response to climate change also depend critically on the spatial and temporal variation of convection processes (see, e.g., Sallée et al., 2012). Due to the coarse spatial resolution in CMIP5 models, convection processes along the continental margin that form the AABW (Antarctic Bottom Water) are not well reproduced (Heuzé et al., 2013). Similarly, Bernardello et al. (2014) suggest that the anthropogenic $\mathrm{CO}_{2}$ uptake in the Weddell Sea is closely linked to the size and timing of deepwater convection. It remains to be investigated how these un- certainties contribute to the inter-model spread of the projected $\mathrm{CO}_{2}$ uptake in the SO shown here, especially with the next round of CMIP6, which includes models with a higher resolution

According to the analysis preformed in this study, improving the representation of amplitude and seasonal phase of contemporary surface $p \mathrm{CO}_{2}$ in $\mathrm{SO}$ has the potential to reduce the uncertainty of the future ocean carbon uptake in CMIP5 models. Bias in amplitude is identified to be associated with the magnitude of primary production in the spring-summer seasons, whereas bias in the seasonal phase is attributed by poor representation of SST seasonal cycle. Seasonally varying surface primary production data along with relevant biogeochemical and ecosystem state variables (e.g., nutrients and oxygen) would help constrain process parameterization in the model. In order to improve the SST simulation, improvements in the representation of physical processes across the air-sea interface and between mixed layer and ocean interior supported by high-quality observation would be needed.

Despite a steady increase in surface $p \mathrm{CO}_{2}$ observations in the SO region over recent decades, it remains markedly undersampled, both spatially and temporally. Presently, there are only very few locations where the full annual cycle of observations is available (Bakker et al., 2014). The SO region also has the largest differences in the net $\mathrm{CO}_{2}$ fluxes as estimated from different methods involving observations and models (Landschützer et al., 2014). Recently, Resplandy et al. (2014) found that DIC-induced small spatial scale $p \mathrm{CO}_{2}$ structures existing in the $\mathrm{SO}$ are non-negligible. Such small-scale processes are generally missing in the coarseresolution CMIP5 models and sparse observations. In addition, the strong interannual variations in the air-sea $\mathrm{CO}_{2}$ fluxes identified in this region (see, e.g., Landschützer et al., 2015; Lovenduski et al., 2015) could also contribute to the discrepancies in the observed and model-simulated $p \mathrm{CO}_{2}$ seasonality presented in this study (see also Hauck et al., 2013).

Beyond surface processes, uncertainties in the subsurface circulation patterns could also contribute to the surface biases simulated in the SO. Here, regions critical for biological production and carbon uptake are associated with mode and intermediate water formation locations (Sarmiento et al., 2004; Sallée et al., 2012). Despite the fact that the simulated net uptake rates of atmospheric $\mathrm{CO}_{2}$ in the $\mathrm{SO}$ are mostly overestimated compared to the values derived from observations (as shown in this study), Frölicher et al. (2015) show that the CMIP5 models underestimate the anthropogenic-carbon storage in the Southern Ocean. This indicates either a shortcoming in the simulated large-scale overturning circulation or too strong a sink of non-anthropogenic carbon simulated here. Therefore, a better constraint of the former mechanism should be prioritized in order to improve the projection of the long-term evolution of air-sea $\mathrm{CO}_{2}$ uptake.

New US-led initiatives that aim to enhance our understanding of the Southern Ocean processes are emerging, 
for instance, the Southern Ocean Carbon and Climate Observation and Modeling project (SOCCOM; http://soccom. princeton.edu). The biogeochemical Argo floats planned to be deployed will provide novel measurements that will help identify how the changing physical processes influence the biogeochemistry dynamics, and vice versa. The EXport Processes in the Ocean from RemoTe Sensing (EXPORT; http: //cce.nasa.gov/cce/ocean.htm) campaign, which studies the export and fate of ocean NPP using remote sensing observations, will also provide a better constraint for ecosystem process parameterization in the model. In addition, a multimodel intercomparison involving observational data such as this study is useful to elucidate the complex interplay among physical and biogeochemical processes, which ultimately would reduce uncertainties in climate projections.

\section{Conclusions}

The latest-generation ESMs project ocean carbon uptake with considerable uncertainty, and this uncertainty is projected to grow 2-fold by the end of the 21 st century under a high future $\mathrm{CO}_{2}$ emissions scenario. In this study, the evaluation of the CMIP5 ESMs was focused on assessing the ability of the models to project the future $\mathrm{CO}_{2}$ fluxes between ocean and atmosphere by looking at the correlation coefficient of each region with the global future ocean $\mathrm{CO}_{2}$ uptake.

We found that the highest inter-model correlation is in the Southern Ocean $(\mathrm{SO})$ region $\left(R_{\text {mean }}^{\mathrm{SO}}=0.76, R_{\mathrm{cum}}^{\mathrm{SO}}=0.65\right)$, meaning that most models agree regarding the evolution of their $\mathrm{CO}_{2}$ uptake behavior through the 21 st century. The majority of models simulate a steady increase in $\mathrm{CO}_{2}$ sink rate due to a weaker decrease in buffer capacity and due to a relatively stable NPP throughout the 21 st century. We show that models that take up anomalously low $\mathrm{CO}_{2}$ in the SO today would project low cumulative $\mathrm{CO}_{2}$ uptake throughout the 21 st century and vice versa. This suggests that the carbon uptake in the SO can be used to constrain future global uptake uncertainty. We highlighted that in other regions, the models simulate a decrease in $\mathrm{CO}_{2}$ uptake during the second half of this century but with a large inter-model spread in the timing of the decreasing trend, thus affecting the multi-model correlation in these areas.

We have identified a strong bias in the amplitude of carbon uptake simulated by the CMIP5 models for the period 2001-2010 in the Southern Ocean, ranging from a source to the atmosphere to a sink almost 3 times more powerful than has been observed $\left(1.03 \pm 0.09\right.$ vs. $0.27 \pm 0.13 \mathrm{PgC} \mathrm{yr}^{-1}$; Lenton et al., 2013). Inter-model spread in the SO carbon sink arises from variations in the surface $p \mathrm{CO}_{2}$ seasonality, which is attributed by the bias in the simulated timing and amplitude of primary production and SST. By analyzing the differences in the simulated $p \mathrm{CO}_{2}$ seasonalities, we classified two groups of models according to two different behaviors. Models that simulate anomalously strong 2001-2010
$\mathrm{CO}_{2}$ uptake in $\mathrm{SO}$ (Fig. 7a, red color) reproduce the observed $p \mathrm{CO}_{2}$ seasonal cycle but its amplitude is 2.5 times stronger than the observation-based estimates. This is because of the strong surface DIC variations, which push down the $p \mathrm{CO}_{2}$ by simulating too strong a biological production. The effect on the projected simulations is an increase in $\mathrm{CO}_{2}$ uptake due to the weaker decrease in seawater $\mathrm{CO}_{2}$ buffering capacity. Other models that simulate anomalously low 2001-2010 $\mathrm{CO}_{2}$ uptake in $\mathrm{SO}$ (Fig. 7a, blue color) simulate a comparable seasonal $p \mathrm{CO}_{2}$ amplitude to that estimated from the observations but a wrong seasonal phase. This is due to the bias in the SST seasonal cycle with stronger amplitude, which tends to push up the $p \mathrm{CO}_{2}$ in January-March, therefore simulating the SO as evolving towards a source of carbon for the atmosphere.

These biases in time and magnitude show the difficulty in simulating the observed marine ecosystem and the biogeochemical processes that contribute and govern the ocean surface $p \mathrm{CO}_{2}$. Consequently, simulating the right contemporary seasonal cycles of biological processes NPP and SST in the Southern Ocean would allow us to constrain the bias in terms of future oceanic carbon flux.

Seasonal timing and amplitude in $p \mathrm{CO}_{2}$ are shown to be critical in order to accurately simulate the present and future $\mathrm{CO}_{2}$ uptake, and therefore accurate monitoring of these biogeochemical processes in the SO is critical in order to constrain the assessment of the contemporary and future ocean carbon sink and subsequently the uncertainty in future climate change. However, the Southern Ocean remains one of the most poorly sampled ocean regions with respect to biogeochemistry. The observational data analyzed here were generated through extrapolations from the limited direct measurements; this could add an extra uncertainty to the analysis. This emphasizes the urgent need for a sustained and comprehensive observational campaign in this region, which is emerging as the key region to better constrain the evolution of future ocean carbon sinks.

Acknowledgements. We thank Catherine Bradshaw for reviewing the earlier version of the manuscript. We thank Ingo Bethke and Nadine Goris for their technical assistance during the CMIP5 model output post-processing. We are also grateful for the constructive feedback from two anonymous referees. We acknowledge the World Climate Research Programme's Working Group on Coupled Modelling, which is responsible for CMIP, and we thank the climate modeling groups (listed in Table 1 of this paper) for producing and making available their model outputs. For CMIP the US Department of Energy's Program for Climate Model Diagnosis and Intercomparison provides coordinating support and led development of software infrastructure in partnership with the Global Organization for Earth System Science Portals. J. Tjiputra acknowledges the Research Council of Norway funded projects ORGANIC (239965/RU), EVA (229771), and VENTILATE (229791/CLE) and the storage resources provided by the Norwegian Storage Infrastructure (NorStore, project ns 1002k). We also acknowledge the EU FP7 Marie Curie International Research 
Staff Exchange Scheme (IRSES) Fellowship SOCCLI "The role of Southern Ocean carbon cycle under climate change (no. 317699)". This is a contribution from the BIGCHANGE project at Bjerknes Centre for Climate Research.

Edited by: C. Franzke

\section{References}

Arora Vivek, K., Boer, G. J., Friedlingstein, P., Eby, M., Jones, C., Christian, J., Bonan, G., Bopp, L., Brovkin, V., Cadule, P., Hajima, T., Ilyina, T., Lindsay, K., Tjiputra, J., and Wu, T.: Carbon concentration and carbon-climate feedbacks in CMIP5 Earth system models, J. Climate, 26, 5289-5314, 2013.

Assmann, K. M., Bentsen, M., Segschneider, J., and Heinze, C.: An isopycnic ocean carbon cycle model, Geosci. Model Dev., 3, 143-167, doi:10.5194/gmd-3-143-2010, 2010.

Atlas, R., Hoffman, R. N., Ardizzone, J., Leidner, S. M., Jusem, J. C., Smith, D. K., and Gombos, D.: A cross-calibrated multiplatform ocean surface wind velocity product for meteorological and oceanographic applications, B. Am. Meteorol. Soc., 92, 157-174, 2011.

Bakker, D. C. E., Pfeil, B., Smith, K., et al.: An update to the Surface Ocean $\mathrm{CO}_{2}$ Atlas (SOCAT version 2), Earth Syst. Sci. Data, 6, 69-90, doi:10.5194/essd-6-69-2014, 2014.

Bernardello, R., Marinov, I., Palter, J. B., Galbraith, E. D., and Sarmiento, J. L.: Impact of Weddell Sea deep convection on natural and anthropogenic carbon in a climate model, Geophys. Res. Lett., 41, doi:10.1002/2014GL061313, 2014.

Bopp, L., Resplandy, L., Orr, J. C., Doney, S. C., Dunne, J. P., Gehlen, M., Halloran, P., Heinze, C., Ilyina, T., Séférian, R., Tjiputra, J., and Vichi, M.: Multiple stressors of ocean ecosystems in the 21st century: projections with CMIP5 models, Biogeosciences, 10, 6225-6245, doi:10.5194/bg-10-6225-2013, 2013.

Carton, J. A. and Giese, B. S.: A reanalysis of ocean climate using Simple Ocean Data Assimilation (SODA), Mon. Weather Rev., 36, 2999-3017, 2008.

Collins, W. J., Bellouin, N., Doutriaux-Boucher, M., Gedney, N., Halloran, P., Hinton, T., Hughes, J., Jones, C. D., Joshi, M., Liddicoat, S., Martin, G., O'Connor, F., Rae, J., Senior, C., Sitch, S., Totterdell, I., Wiltshire, A., and Woodward, S.: Development and evaluation of an Earth-System model - HadGEM2, Geosci. Model Dev., 4, 1051-1075, doi:10.5194/gmd-4-10512011, 2011.

Denman, K. L., Brasseur, G., Chidthaisong, A., Ciais, P., Cox, P. M., Dickinson, R. E., Hauglustaine, D., Heinze, C., Holland, E., Jacob, D., Lohmann, U., Ramachandran, S., da Silva Dias, P. L., Wofsy, S. C., and Zhang, X.: Couplings between changes in the climate system and biogeochemistry, in: Climate Change 2007: The Physical Science Basis, Contribution of Working Group I to the Fourth Assessment Report of the Intergovernmental Panel on Climate Change, edited by: Solomon, S., Qin, D., Manning, M., Chen, Z., Marquis, M., Averyt, K. B., Tignor, M., and Miller, H. L., Cambridge University Press, Cambridge, UK and New York, NY, USA, 499-587, 2007.

Dickson, A. G., and Millero, F. J.: A comparison of the equilibrium constants for the dissociation of carbonic acid in seawater media, Deep-Sea Res., 34, 1733-1743, 1987.
Dunne, J. P., John, J. G., Adcroft, A. J., Griffies, S. M., Hallberg, R. W., Shevliakova, E., Stouffer, R. J., Cooke, W., Dunne, K. A., Harrison, M. J., Krasting, J. P., Malyshev, S. L., Milly, P. C. D., Phillipps, P. J., Sentman, L. T., Samuels, B. L., Spelman, M. J., Winton, M., Wittenberg, A. T., and Zadeh, N.: GFDL's ESM2 global coupled climate-carbon Earth System Models Part I: Physical formulation and baseline simulation characteristics, J. Climate, 25, 6646-6665, doi:10.1175/JCLI-D-11-00560.1, 2012.

Feely, R. A., Takahashi, T., Wanninkhof, R., McPhaden, M. J., Cosca, C. E., Sutherland, S. C., and Carr, M.-E.: Decadal variability of the air-sea $\mathrm{CO}_{2}$ fluxes in the equatorial Pacific Ocean, $\mathrm{J}$. Geophys. Res., 111, C08S90, doi:10.1029/2005JC003129, 2006.

Friedlingstein, P., Andrew, R. M., Rogelj, J., Peters, G. P., Canadell, J. G., Knutti, R., Luderer, G., Raupach, M. R., Schaeffer, M., Van Vuuren, D. P., and Le Quéré, C.: Persistent growth of $\mathrm{CO}_{2}$ emissions and implications for reaching climate targets, Nat. Geosci., 7, 709-715, 2014.

Frölicher, T. L., Sarmiento, J. L., Paynter, D. J., Dunne, J. P., Krasting, J. P., and Winton, M.: Dominance of the Southern Ocean in anthropogenic carbon and heat uptake in CMIP5 models, J. Climate, 28, 862-886, doi:10.1175/JCLI-D-14-00117.1, 2015.

Fuss, S., Canadell, J. G., Peters, G. P., Tavoni, M., Andrew, R. M., Ciais, P., Jackson, R. B., Jones, C. D., Kraxner, F., Nakicenovic, N., Le Quéré, C., Raupach, M. R., Sharifi, A., Smith, P., and Yamagata, Y.: Betting on negative emissions, Nature Clim. Change, 4, 850-853, doi:10.1038/nclimate2392, 2014.

Gent, P. R., Danabasoglu, G., Donner, L. J., Holland, M. M., Hunke, E. C., Jayne, S. R., Lawrence, D. M., Neale, R. B., Rasch, P. J., Vertenstein, M., Worley, P. H., Yang, Z.-L., and Zhang, M.: The community climate system model version 4., J. Climate, 24, 4973-4991, 2011.

Gillett, N. P. and Fyfe, J. C.: Annular mode changes in the CMIP5 simulations, Geophys. Res. Lett., 40, 1189-1193, 2013.

Giorgetta, M. A., Jungclaus, J. H., Reick, C. H., Legutke, S., Brovkin, V., Crueger, T., Esch, M., Fieg, K., Glushak, K., Gayler, V., Haak, H., Hollweg, H.-D., Ilyina, T., Kinne, S., Kornblueh, L., Matei, D., Mauritsen, T., Mikolajewicz, U., Mueller, W. A., Notz, D., Raddatz, T., Rast, S., Redler, R., Roeckner, E., Schmidt, H., Schnur, R., Segschneider, J., Six, K., Stockhause, M., Wegner, J., Widmann, H., Wieners, K.-H., Claussen, M., Marotzke, J., and Stevens, B.: Climate change from 1850 to 2100 in MPI-ESM simulations for the Coupled Model Intercomparison Project 5, J. Adv. Model. Earth Syst., 5, 572-597, 2013.

Hauck, J., Völker, C., Wang, T., Hoppema, M., Losch, M., and Wolf-Gladrow, D. A.: Seasonality different carbon flux changes in the Southern Ocean in response to the southern annular mode, Global Biogeochem. Cy., 27, 1236-1245, doi:10.1002/2013GB004600, 2013.

Hauck, J. and Völker, C.: Rising atmospheric $\mathrm{CO}_{2}$ leads to large impact of biology on Southern Ocean $\mathrm{CO}_{2}$ uptake via changes of the Revelle factor, Geophys. Res. Lett., 42, 1459-1464, 2015.

Heinze, C., Meyer, S., Goris, N., Anderson, L., Steinfeldt, R., Chang, N., Le Quéré, C., and Bakker, D. C. E.: The ocean carbon sink - impacts, vulnerabilities and challenges, Earth Syst. Dynam., 6, 327-358, doi:10.5194/esd-6-327-2015, 2015.

Heuzé, C., Heywood, K. J., Stevens, D. P., and Ridley, J. K.: Southern Ocean bottom water charateristics in CMIP5 models, Geophys. Res. Lett., 40, 1409-1414, 2013. 
Ilyina, T., Six, K. D., Segschneider, J., Maier-Reimer, E., Li, H., and Nunez-Riboni, I.: The global ocean biogeochemistry model HAMOCC: model architecture and performance as component of the MPI-Earth System Model in different CMIP5 experimental realizations, J. Adv. Model. Earth Syst., 5, 1-29, 2013.

Jiang, C. L., Gille, S. T., Sprintall, J, and Sweeney, C.: Drake passage oceanic $p \mathrm{CO}_{2}$ : evaluating CMIP5 coupled carbonclimate models using in situ observations, J. Climate, 27, 76100, doi:10.1175/JCLI-D-12-00571.1, 2014.

Kahru, M. and Mitchell, G.: Blending of ocean colour algorithms applied to the Southern Ocean, Remote Sens. Lett., 1, 119-124, 2010.

Landschützer, P., Gruber, N., Bakker, D. C. E., Schuster, U., Nakaoka, S., Payne, M. R., Sasse, T. P., and Zeng, J.: A neural network-based estimate of the seasonal to inter-annual variability of the Atlantic Ocean carbon sink, Biogeosciences, 10, 7793-7815, doi:10.5194/bg-10-7793-2013, 2013.

Landschützer, P., Gruber, N., Bakker, D. C. E., and Schuster, U.: Recent variability of the global ocean carbon sink, Global Biogeochem. Cy., 28, 927-949, doi:10.1002/2014GB004853, 2014.

Landschützer, P., Gruber, N., Haumann, F. A., Rödenbeck, C., Bakker, D. C. E., van Heuven, S., Hoppema, M., Metzl, N., Sweeney, C., Takahashi, T., Tilbrook, B., and Wanninkhof, R.: The reinvigoration of the Southern Ocean carbon sink, Science, 349, 1221-1224, 2015.

Laufkötter, C., Vogt, M., Gruber, N., Aita-Noguchi, M., Aumont, O., Bopp, L., Buitenhuis, E., Doney, S. C., Dunne, J., Hashioka, T., Hauck, J., Hirata, T., John, J., Le Quéré, C., Lima, I. D., Nakano, H., Seferian, R., Totterdell, I., Vichi, M., and Völker, C.: Drivers and uncertainties of future global marine primary production in marine ecosystem models, Biogeosciences, 12, 69556984, doi:10.5194/bg-12-6955-2015, 2015.

Lee, K., Tong, L. T., Millero, F. J., Sabine, C. L., Dickson, A. G., Goyet, C., Park, G.-H., Wanninkhof, R., Feely, R. A., and Key, R. M.: Global relationships of total alkalinity with salinity and temperature in surface waters of the world's oceans, Geophys. Res. Lett., 33, L19605, doi:10.1029/2006GL027207, 2006.

Lenton, A., Tilbrook, B., Law, R. M., Bakker, D., Doney, S. C., Gruber, N., Ishii, M., Hoppema, M., Lovenduski, N. S., Matear, R. J., McNeil, B. I., Metzl, N., Mikaloff Fletcher, S. E., Monteiro, P. M. S., Rödenbeck, C., Sweeney, C., and Takahashi, T.: Sea-air $\mathrm{CO}_{2}$ fluxes in the Southern Ocean for the period 19902009, Biogeosciences, 10, 4037-4054, doi:10.5194/bg-10-40372013, 2013.

Le Quéré, C., Rödenbeck, C., Buitenhuis, E. T., Conway, T. J., Langenfelds, R., Gomez, A., Labuschagne, C., Ramonet, M., Nakazawa, T., Metzl, N., Gillett, N., and Heimann, M.: Saturation of the Southern Ocean $\mathrm{CO}_{2}$ sink due to recent climate change, Science, 316, 1735-1738, 2007.

Le Quéré, C., Moriarty, R., Andrew, R. M., Canadell, J. G., Sitch, S., Korsbakken, J. I., Friedlingstein, P., Peters, G. P., Andres, R. J., Boden, T. A., Houghton, R. A., House, J. I., Keeling, R. F., Tans, P., Arneth, A., Bakker, D. C. E., Barbero, L., Bopp, L., Chang, J., Chevallier, F., Chini, L. P., Ciais, P., Fader, M., Feely, R. A., Gkritzalis, T., Harris, I., Hauck, J., Ilyina, T., Jain, A. K., Kato, E., Kitidis, V., Klein Goldewijk, K., Koven, C., Landschützer, P., Lauvset, S. K., Lefèvre, N., Lenton, A., Lima, I. D., Metzl, N., Millero, F., Munro, D. R., Murata, A., Nabel, J. E. M. S., Nakaoka, S., Nojiri, Y., O’Brien, K., Olsen, A., Ono, T., Pérez,
F. F., Pfeil, B., Pierrot, D., Poulter, B., Rehder, G., Rödenbeck, C., Saito, S., Schuster, U., Schwinger, J., Séférian, R., Steinhoff, T., Stocker, B. D., Sutton, A. J., Takahashi, T., Tilbrook, B., van der Laan-Luijkx, I. T., van der Werf, G. R., van Heuven, S., Vandemark, D., Viovy, N., Wiltshire, A., Zaehle, S., and Zeng, N.: Global Carbon Budget 2015, Earth Syst. Sci. Data, 7, 349-396, doi:10.5194/essd-7-349-2015, 2015.

Lindsay, K., Bonan, G. B., Doney, S. C., Hoffman, F. M., Lawrence, D. M., Long, M. C., Mahowald, N. M., Moore, J. K., Randerson, J. T., and Thornton, P. E.: Preindustrial-control and twentieth-century carbon cycle experiments with the Earth system model CESM1(BGC), J. Climate, 27, 8981-9005, doi:10.1175/JCLI-D-12-00565.1, 2014.

Lovenduski, N. S., Fay, A. R., and McKinley, G. A.: Observing multidecadal trends in Southern Ocean $\mathrm{CO}_{2}$ uptake: What can we learn from an ocean model?, Global Biogeochem. Cy., 29, 416-426, 2015.

Merlivat, L., Boutin, J., and Antoine, D.: Roles of biological and physical processes in driving seasonal air-sea $\mathrm{CO}_{2}$ flux in the Southern Ocean: new insights from CARIOCA $p \mathrm{CO}_{2}$, J. Marine Syst., 147, 9-20, 2015.

Marinov, I., Gnanadesikan, A., Toggweiler, J. R., and Sarmiento, J. L.: The Southern Ocean biogeochemical divide, Nature, 441, 964-967, 2007.

Mehrbach, C., Culberson, C. H., Hawley, J. E., and Pytkwicz, R. M.: Measurement of the apparent dissociation constants of carbonic acid in seawater at atmospheric pressure, Limnol. Oceanogr., 18, 897-907, 1973.

Mikaloff Fletcher, S. E., Gruber, N., Jacobson, A. R., Gloor, M., Doney, S. C., Dutkiewicz, S., Gerber, M., Follows, M., Joos, F., Lindsay, K., Menemenlis, D., Mouchet, A., Müller, S. A., and Sarmiento, J. L.: Inverse estimates of the oceanic sources and sinks of natural $\mathrm{CO}_{2}$ and the implied oceanic carbon transport, Global Biogeochem. Cy., 21, GB1010, doi:10.1029/2006GB002751, 2007.

Nevison, C. D., Manizza, M., Keeling, R. F., Kahru, M., Bopp, L., Dunne, J., Tiputra, J., Ilyina, T., and Mitchell, B. G.: Evaluating the ocean biogeochemical components of Earth system models using atmospheric potential oxygen and ocean color data, Biogeosciences, 12, 193-208, doi:10.5194/bg-12-193-2015, 2015.

Oschlies, A.: NAO-induced long-term changes in nutrient supply to the surface waters of the North Atlantic, Geophys. Res. Lett., 28, 1751-1754, 2001.

Palmer, J. R. and Totterdell, I. J.: Production and export in a global ecosystem model, Deep-Sea Res. Pt. I, 48, 1169-1198, 2001.

Peters, G. P., Andrew, R. M., Boden, T., Canadell, J. G., Ciais, P., Le Quéré, C., Marland, G., Raupach, M. R., and Wilson, C.: The challenge to keep global warming below $2{ }^{\circ} \mathrm{C}$, Nature Clim. Change, 3, 4-6, 2013.

Rahmstorf, S., Box, J. E., Feulner, G., Mann, M. E., Robinson, A., Rutherford, S., and Schaffernicht, E. J.: Exceptional twentiethcentury slowdown in Atlantic Ocean overturning circulation, Nature Clim. Change, 5, 475-480, 2015.

Resplandy, L., Boutin, J., and Merlivat, L.: Observed small spatial scale and seasonal variability of the $\mathrm{CO}_{2}$ system in the Southern Ocean, Biogeosciences, 11, 75-90, doi:10.5194/bg-11-75-2014, 2014. 
Revelle, R. and Suess, H. E.: Carbon dioxide exchange between atmosphere and ocean and the question of an increase of atmospheric $\mathrm{CO}_{2}$ during the past decades, Tellus, 9, 18-27, 1957.

Reynolds, R. W., Rayner, N. A., Smith, T. M., Stokes, D. C., and Wang, W.: An improved in situ and satellite SST analysis for climate, J. Climate, 15, 1609-1625, 2002.

Rodgers, K. B., Aumont, O., Mikaloff Fletcher, S. E., Plancherel, Y., Bopp, L., de Boyer Montégut, C., Iudicone, D., Keeling, R. F., Madec, G., and Wanninkhof, R.: Strong sensitivity of Southern Ocean carbon uptake and nutrient cycling to wind stirring, Biogeosciences, 11, 4077-4098, doi:10.5194/bg-11-4077-2014, 2014.

Roy, T., Bopp, L., Gehlen, M., Schneider, B., Cadule, P., Frolicher, T. L., Segschneider, J., Tjiputra, J., Heinze, C., and Joos, F.: Regional impacts of climate change and atmospheric $\mathrm{CO}_{2}$ on future ocean carbon uptake: a multimodel linear feedback analysis, J. Climate, 24, 5195-5195, 2011.

Sabine, C. L., Feely, R. A., Gruber, N., Key, R. M., Lee, K., Bullister, J. L., Wanninkhof, R., Wong, C. S., Wallace, D. W. R., Tilbrook, B., Millero, F. J., Peng, T., Kozyr, A., Ono, T., and Rios, A. F.: The oceanic sink for anthropogenic $\mathrm{CO}_{2}$, Science, 305, 367-374, 2004.

Sallée, J. B., Matear, R. J., Rintoul, S. R., and Lenton, A.: Localized subduction of anthropogenic carbon dioxide in the Southern Hemisphere oceans, Nat. Geosci., 5, 579-584, 2012.

Sallée, J. B., Shuckburgh, E., Bruneau, N., Meijers, A. J. S., Bracegirdle, T. J., Wang, Z., and Roy, T.: Assessment of Southern Ocean water mass circulation and characteristics in CMIP5 models: historical bias and forcing response, J. Geophys. Res.Oceans, 118, 1830-1844, doi:10.1002/jgrc.20135, 2013a.

Sallée, J. B., Shuckburgh, E., Bruneau, N., Meijers, A. J. S., Bracegirdle, T. J., and Wang, Z.: Assessment of Southern Ocean mixed layer depths in CMIP5 models: historical bias and forcing response, J. Geophys. Res.-Oceans, 118, 1845-1862, doi:10.1002/jgrc.20157, 2013b.

Sarmiento, J. L., Hughes, T. M. C., Stouffer, R. J., and Manabe, S.: Simulated response of the ocean carbon cycle to anthropogenic climate warming, Nature, 393, 245-249, 1998.

Sarmiento, J. L., Gruber, N., Brzezinski, M. A., and Dunne, J. P.: High-latitude controls of thermocline nutrients and low latitude biological productivity, Nature, 427, 56-60, 2004.

Séférian, R., Iudicone, D., Bopp, L., Roy, T., and Madec, G.: Water mass analysis of effect of climate change on air-sea $\mathrm{CO}_{2}$ fluxes: The Southern Ocean, J. Climate, 25, 3894-3908, 2012.

Takahashi, T., Sutherland, S. C., Sweeney, C., Poisson, A., Metzl, N., Tilbrook, B., Bates, N.,Wanninkhof, R., Feely, R. A., Sabine, C., lafsson, J., and Nojiri, Y.: Global sea-air $\mathrm{CO}_{2}$ flux based on climatological surface ocean $p \mathrm{CO}_{2}$ and seasonal biological and temperature effects, Deep-Sea Res. Pt. II, 49, 16011622, 2002.

Takahashi, T., Sutherland, S. C., Wanninkhof, R., Sweeney, C., Feely, R. A., Chipman, D. W., Hales, B., Friedrich, G., Chavez, F., Sabine, C., Watson, A., Bakker, D. C. E., Schuster, U., Metzl, N., Yoshikawa-Inoue, H., Ishii, M., Midorikawa, T., Nojiri, Y., Körtzinger, A., Steinhoff, T., Hoppema, M., Olafsson, J., Arnarson, T. S., Tilbrook, B., Johannessen, T., Olsen, A., Bellerby, R., Wong, C. S., Delille, B., Bates, N. R., and de Baar, H. J. W.: Climatological mean and decadal change in surface ocean $p \mathrm{CO}_{2}$, and net sea-air $\mathrm{CO}_{2}$ flux over the global oceans, Deep-Sea Res. II, 56, 554-577, doi:10.1016/j.dsr2.2008.12.009, 2009.

Taylor, K. E., Stouffer, R. J., and Meehl, G. A.: An overview of CMIP5 and the experiment design, B. Am. Meteorol. Soc., 93, 485-498, 2012.

Tjiputra, J. F., Roelandt, C., Bentsen, M., Lawrence, D. M., Lorentzen, T., Schwinger, J., Seland, Ø., and Heinze, C.: Evaluation of the carbon cycle components in the Norwegian Earth System Model (NorESM), Geosci. Model Dev., 6, 301-325, doi:10.5194/gmd-6-301-2013, 2013.

Tjiputra, J. F., Olsen, A., Bopp, L., Lenton, A., Pfeil, B., Roy, T., Segschneider, J., Totterdell, I., and Heinze, C.: Long-term surface $p \mathrm{CO}_{2}$ trends from observations and models, Tellus $\mathrm{B}, 66$, 23083, doi:10.3402/tellusb.v66.23083, 2014.

van Heuven, S.,Pierrot, D., Rae, J. W. B., Lewis, E., and Wallace, D. W. R.: Matlab program developed for CO2 system calculations. ornl/cdiac-105b., Carbon Dioxide Information Analysis Center, Oak Ridge National Laboratory, US Department of Energy, Oak Ridge, Tennessee, http://cdiac.ornl.gov/ftp/co2sys/ CO2SYS_calc_MATLAB_v1.1/ (last access: April 2016), 2011.

Volk, T. and Hoffert, M. I.: Ocean carbon pumps: Analysis of relative strengths and efficiencies in ocean-driven atmospheric $\mathrm{CO}_{2}$ changes, in: The Carbon Cycle and Atmospheric $\mathrm{CO}_{2}$ : Natural Variations Archean to Present, edited by: Sundquist, E. T. and Broecker, W. S., 99-110, AGU, Washington, D. C., 1985.

Wallace, D.: Storage and transport of excess $\mathrm{CO}_{2}$ in the oceans: the JGOFS/WOCE global $\mathrm{CO}_{2}$ survey, in: Ocean Circulation and Climate: Observing and Modelling the Global Ocean, edited by: Siedler, J., Church, J., and Gould, J., Academic Press, San Diego, CA, 489-521, 2001.

Watanabe, S., Hajima, T., Sudo, K., Nagashima, T., Takemura, T., Okajima, H., Nozawa, T., Kawase, H., Abe, M., Yokohata, T., Ise, T., Sato, H., Kato, E., Takata, K., Emori, S., and Kawamiya, M.: MIROC-ESM 2010: model description and basic results of CMIP5-20c3m experiments, Geosci. Model Dev., 4, 845-872, doi:10.5194/gmd-4-845-2011, 2011.

Wu, T., Li, W., Ji, J., Xin, X., Li, L., Wang, Z., Zhang, Y., Li, J., Zhang, F., Wei, M., Shi, X., Wu, F., Zhang, L., Chu, M., Jie, M., Liu, Y., Wang, F., Liu, X., Li, Q., Dong, M., Liang, X., Gao, Y., and Zhang, J.: Global carbon budgets simulated by the Beijing Climate Center Climate System Model for the last century, J. Geophys. Res.-Atmos., 118, 4326-4347, 2013.

Yukimoto, S., Adachi, Y., Hosaka, M., Sakami, T., Yoshimura, H., Hirabara, M., Tanaka, T. Y., Shindo, E., Tsujino, H., Deushi, M., Mizuta, R., Yabu, S., Obata, A., Nakano, H., Koshiro, T., Ose, T., and Kitho, A.: A New global climate model of the Meteorological Research Institute: MRI-CGCM3, J. Meteorol. Soc. Jpn., 90A, 23-64, 2012.

Zeebe, R. and Wolf-Gladrow, D.: $\mathrm{CO}_{2}$ in Seawater: Equilibrium, Kinetics, Isotopes, Elsevier Oceanogr. Ser., vol. 65, Elsevier, Amsterdam, the Netherlands, 346 pp., 2001. 